\title{
Communities in Crisis: Interior Removals and Their Human Consequences
}
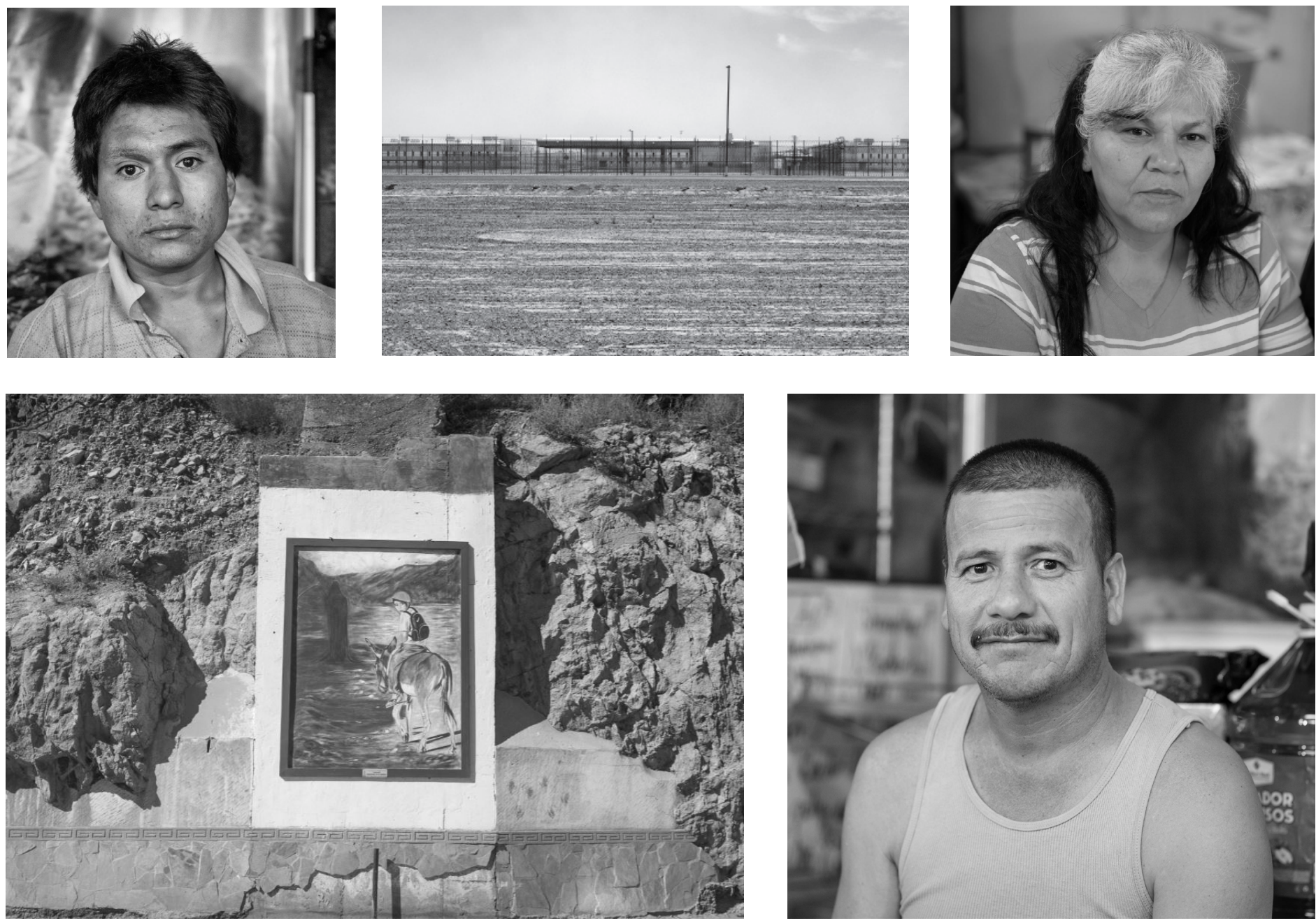

Kino Border Initiative Iniciativa Kino para la Frontera
46. CMS

IIIS Office of Justice and Ecology 
The CRISIS Study (Catholic Removal Impact Survey in Society) represents a collaboration by the Kino Border Initiative (KBI), the Center for Migration Studies of New York (CMS), and the Office of Justice and Ecology (OJE) of the Jesuit Conference of Canada and the United States. The study benefitted from significant contributions by: Father Sean Carroll, SJ and Joanna Williams of KBI who organized the initiative; Joanna Williams, Sister Maria Engracia Robles, ME, and Sister Maribel Lara Hernández, ME of KBI who conducted the survey of deportees; Daniela Alulema of CMS and Elizabeth Vincent of OJE who interviewed families and others affected by deportation in three communities; the pastors and staff of the Catholic parishes in Florida, Michigan, and Minnesota who arranged and hosted the interviews; Katie Dingeman, assistant professor at the California State University, Los Angeles, and Rebecca Galemba, assistant professor at the University of Denver, who developed the Kino survey instruments and interview guides; Mike Nicholson of CMS who analyzed the survey results and produced the report's charts; Father Ted Penton, SJ of OJE and every member of the research team who offered comments and edits to the report; Kristen Lionetti for her guidance and early contributions to the project; Samantha Kunin and Lucy McAuliffe, CMS interns, who assisted with data collection; and the report's authors Donald Kerwin, Daniela Alulema, and Mike Nicholson of CMS.

The $\mathrm{KBI}, \mathrm{CMS}$, and OJE team particularly thank the immigrants, families, and parish community members who shared their experiences and made the study possible.

Kino Border Initiative Iniciativa Kino para la Frontera
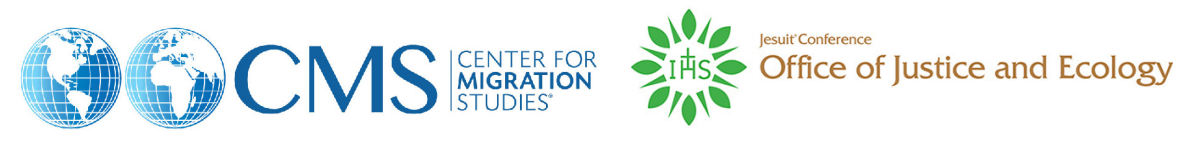

(C) $2018 \mathrm{KBI}, \mathrm{CMS}$, and OJE.

All Rights Reserved.

Cover photo credits and description:

Top left, a young man at the Kino Border Initiative aid center in Nogales, Sonora (Larry Hanelin); top middle, Eloy Detention Center in Arizona (Greg Constantine); top right, a woman at the Kino Border Initiative aid center in Nogales, Sonora (Larry Hanelin). Bottom left, a painting in downtown Nogales, Sonora along the wall as a warning of the dangers that people face in the desert (Larry Hanelin); bottom right, Florencio, who was deported from Arizona after 16 years living there and left behind four children (Larry Hanelin).

Suggested citation:

Kerwin, Donald, Daniela Alulema, and Mike Nicholson. 2018. Communities in Crisis: Interior Removals and Their Human Consequences. Nogales, AZ, New York, NY, and Washington, DC: Kino Border Initiative (KBI), Center for Migration Studies (CMS), and Office of Justice and Ecology (OJE). https://doi. org/10.14240/rpt1118. 


\section{Communities in Crisis: Interior Removals and Their Human Consequences}

A report of the Kino Border Initiative, Center for Migration Studies, and Office of Justice and Ecology 


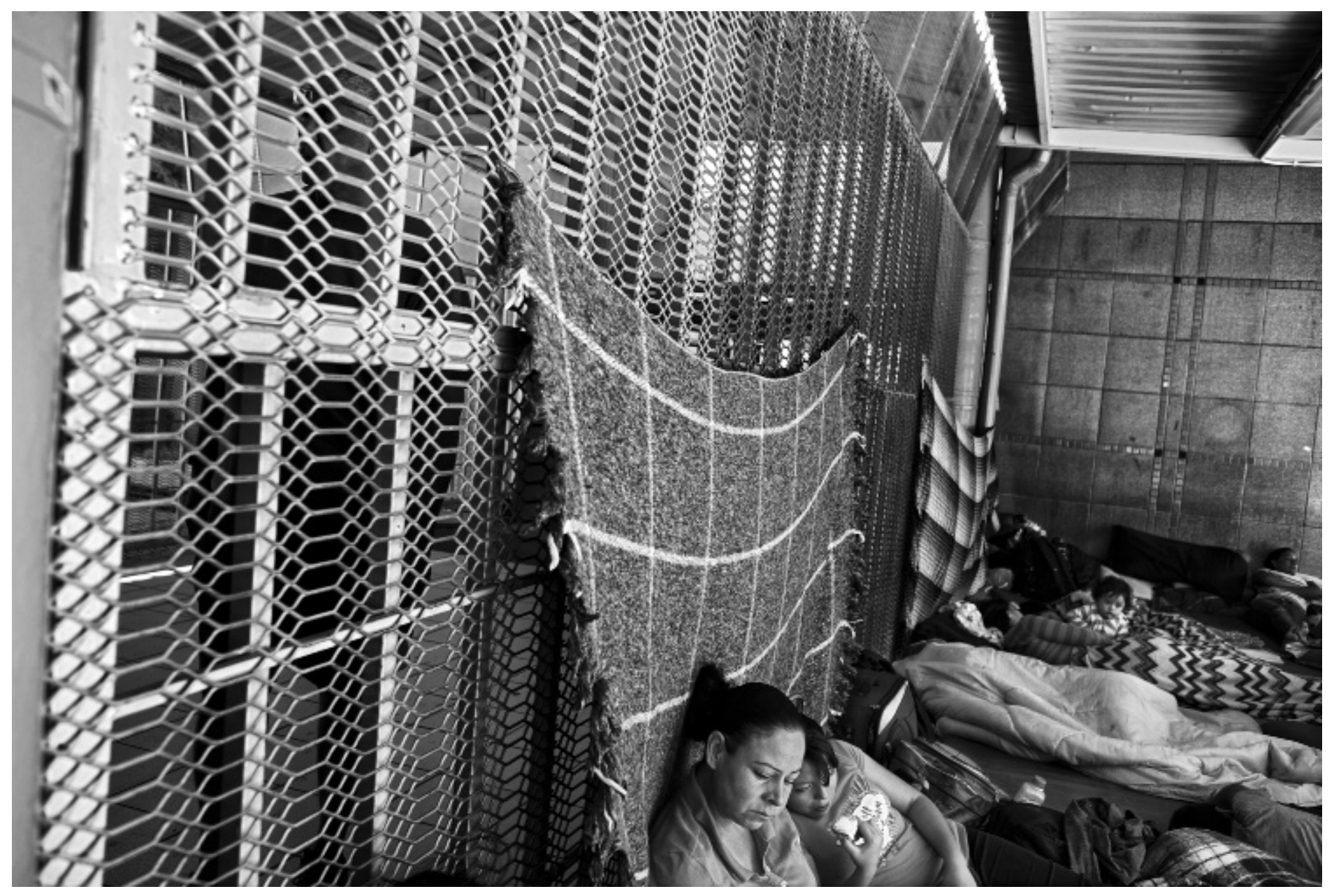

A woman and her child waiting at the port of entry in Nogales, Sonora to be processed into the US asylum system. Photo: Greg Constantine. 


\section{Communities in Crisis: Interior Removals and Their Human Consequences}

"My oldest son asks, 'Where are my rights as a US citizen? Where is my right to live with my family and have a home?"”

- Mother of three US citizen children and wife of detained immigrant

"My husband called and said that he had a normal check-in like every year. He went like always, but this time they arrested him. I asked why if everything was going well. He had a clean record. He is a good father. He is working to help our kids get ahead. We have two children who are citizens and we are fighting for them, so that they are good people and professionals. I didn't see any reason for him to get arrested."

- Woman whose husband was deported

"In my preaching, I guide and insist that it is important to be aware of our rights, to not have fear, and to know that we all are God's children and need a piece of land in this planet. I try to remind them that they are immigrants but also human beings before anything else and that all human beings have rights."

- Priest

\section{Executive Summary}

In late 2017, the Kino Border Initiative (KBI), the Center for Migration Studies of New York (CMS), and the Office of Justice and Ecology (OJE) of the Jesuit Conference of Canada and the United States initiated a study to examine the characteristics of deportees and the effects of deportation, and to place them in a broader policy context (Attachment A). ${ }^{1}$

The CRISIS Study (Catholic Removal Impact Survey in Society) included both quantitative and qualitative elements. During the first five months of 2018, KBI staff surveyed 133 deportees from the United States at its migrant shelter in Nogales, Sonora. Survey respondents were all Mexican nationals, all but one were men, and each had been living for a period of time in the United

$1 \mathrm{KBI}$, which operates in Nogales, Arizona and Nogales, Sonora, seeks "to promote US/Mexico border and immigration policies that affirm the dignity of the human person and a spirit of binational solidarity." KBI provides humanitarian assistance and accompaniment to migrants; social and pastoral education with communities on both sides of the border; and research and advocacy. CMS is a think tank and an educational institute devoted to the study of international migration, to the promotion of understanding between immigrants and receiving communities, and to public policies that safeguard the dignity and rights of migrants, refugees, and newcomers. CMS is a member of the Scalabrini International Migration Network (SIMN), a global network of migrant shelters, service centers, and other institutions, and the Scalabrini Migration Study Centers. OJE of the Jesuit Conference of Canada and United States seeks to foster reconciliation on issues such as refugee protection, immigration, and economic, criminal, juvenile, and environmental justice. 
States. ${ }^{2}$ They had resided in 16 US states, the majority in Arizona, followed by Nevada, California, and Utah. The survey sought information on their US lives, the removal and detention process, and the impact of removal on them and their families (Attachment B).

The study also included one interview with a deportee (via Skype) and 20 interviews with the family members of deportees and other persons affected by deportation in Catholic parishes in Florida, Michigan, and Minnesota. The parishes - which the report will not identify in order to ensure the interviewees' anonymity - were chosen based on their geographic, demographic, and sociopolitical diversity, their connections to the agencies conducting the study, and their ability to facilitate access to deportees, their families, and others impacted by deportation.

The interviews explored: (1) the impact of removals on deportees, their families, and other community members; (2) the deportation process; and (3) the relationship between deportees and their families (Attachment C). They provided an intimate, often raw look at the human consequences of deportation.

\section{Long Tenure, Homeownership, Legal Status, and Community Engagement}

By and large, survey respondents had built their lives, made their homes, and established long and deep ties in the United States.

- On average, they had lived in the United States for 19.9 years.

- More than half (56 percent) first entered the country as minors (below age 18), and 21 percent below age 10.

- Thirty-eight percent reported having legal status in the United States, including 14.3 percent who were lawful permanent residents (LPRs).

- Twenty-six percent had been US homeowners.

- Fifty-two percent had participated in church activities, 34.1 percent regularly attended church services, and 9 percent had participated in community organizations.

\section{Family and Economic Ties and the Consequences of Deportation}

Survey respondents had established strong family and economic ties in the United States. Deportation mostly severed these ties, and divided, devastated, and impoverished the affected families.

- Seventy-eight percent of survey respondents had US citizen children. ${ }^{3}$

- The average age of respondents' children living in the United States was 14.9 and 33 percent were 10 years old or less.

- Forty-two percent had US citizen spouses or partners. ${ }^{4}$

- Ninety-six percent had been employed in the United States.

2 The report uses the phrase "interior removals" to refer to the deportation of persons who have been living in the United States for a period of time.

3 Respondents were asked to list the age, residency, and citizenship status of up to five children.

4 This figure refers to respondents with spouses or domestic partners. 
- On average, they had worked nearly 10 years in the same job and earned roughly $\$ 2,800$ per month.

- Respondents had an average of $\$ 142$ in their possession at the time of their deportation. ${ }^{5}$

- Deportees reported that they needed employment (78.2 percent), financial (68.4 percent), housing (56.4 percent), emotional (56.4 percent), and social integration (54.9 percent) assistance.

- Most survey respondents reported that their spouse or partner in the United States did not have enough money to support their children (74 percent) or to live on (63 percent).

- Respondents identified a range of close family members who depended on them financially prior to their deportation, including their mothers (72 percent), fathers (57 percent), and siblings (26 percent).

- Forty percent reported having dependents with chronic health or psychological conditions, including heart disease, cancer, diabetes, and autism.

- Nearly one-half (48.1 percent) said that their children - some of whom lived in the United States and some in Mexico - were experiencing difficulties in school.

\section{Plans to Return to the United States}

Given the strong ties binding survey respondents to the United States, it comes as little surprise that:

- Three-quarters (73.5 percent) reported that they planned to return to the United States.

- Forty-five percent identified only a little or "not at all" with their country of birth.

- Only one-third (35.4) percent reported feeling safe since their deportation.

\section{The Criminalization of Deportation}

The Trump administration has regularly portrayed undocumented residents, migrants seeking to request asylum at the US-Mexico border, and deportees as criminals and security threats. Most survey respondents either had not been convicted of a crime or had committed an immigration or traffic offense prior to their deportation. Nevertheless, study participants described a deportation system that treated them as criminals and instilled fear in their communities.

- Nearly one-half of respondents said they had not been convicted of a crime prior to their deportation.

- Of the 37 respondents (51.4 percent) who reported having been convicted of a crime, ${ }^{6}$ more than one-third (35.1 percent) had been convicted of a traffic or immigration offense, 21.6 percent of a drug-related crime (including possession), and another 21.6 percent of a violent crime. $^{7}$

5 Mexican pesos were converted into dollars using prevailing exchange rates on August 19, 2018.

6 Only 72 respondents answered this question.

7 The study classified these self-reported crimes based on the National Crime Information Center's (NCIC) uniform offense codes. 
- A high percent of respondents (65.2) reported that their deportation began with a police arrest, 30.3 percent reported having been arrested by Immigration and Customs Enforcement (ICE), and less than 1 percent by Customs and Border Protection (CBP).

- The majority of apprehensions took place while respondents were driving (36.1 percent), at home (26.3 percent), or at work (6 percent).

- Survey respondents spent an average of 96 days in immigrant detention. Most were detained for 30 days or less, and 17 percent were detained for 180 days or more.

- Only 28 percent were able to secure legal counsel.

- Roughly one-fourth of survey respondents reported spending no time in criminal custody and 22.6 percent spent a week or less prior to their deportation. However, 17.3 percent spent more than one year.

\section{Recommendations}

The CRISIS Study provides a snapshot of the Trump administration's deportation policies and their effect on established US residents (deportees), families, and communities. In order to mitigate the harsh consequences of these policies and promote the integrity of families and communities, we make the following recommendations.

To the Department of Homeland Security:

- Issue prosecutorial discretion guidelines that de-prioritize the arrest and removal of longterm residents; persons with US family members; and those without criminal records or with records for only minor offenses.

- Use detention only as a "last resort" and employ the least restrictive means necessary - including supervised release and other alternatives to detention (ATDs) - to ensure appearances in court, check-ins with immigration officials, and possible removal.

- Adhere to ICE's National Detention Standards, which recognize the need for access to legal counsel, generous family visitation guidelines, transparency regarding the location of detainees, and humane conditions of confinement.

\section{To Congress:}

- Pass broad legislation to reduce family-based visa backlogs; to align US legal immigration policies with the nation's economic, family, and humanitarian interests; to legalize the undocumented parents of US citizens and LPRs and undocumented persons who entered as children; and to expand equitable relief from removal.

- Appropriate funding to the Department of Homeland Security (DHS) and the Department of Justice at levels that align with the recommendations in this report and that, in particular, assume the principled exercise of prosecutorial discretion, reduced use of detention, and expansion of community-based ATDs and legal orientation programs.

- Reduce funding to ICE in light of its indiscriminate enforcement policies and their negative impact on the safety and integrity of US families and communities. 
- Provide greater oversight of formal partnerships and collaboration between state and local police and ICE and CBP to ensure that these arrangements do not undermine community safety or lead to racial profiling.

\section{To state and local police:}

- Collect data to measure the prevalence of pretextual police stops and arrests (intended to lead to removal) for minor criminal violations, with a focus on the extent to which such stops involve racial and ethnic minorities.

- Limit collaboration with ICE and CBP to prevent local police from acting as immigration agents, to promote public safety, and to ensure that no group of residents fears reporting crimes or otherwise cooperating with the police.

- Strengthen policies against racial bias in policing, and regularly train and evaluate law enforcement officers on adherence to these policies.

- Adopt and implement policies - like municipal identification cards and driver's licenses for the undocumented - that treat immigrants as full members of their communities.

\section{To faith communities:}

- Address the urgent priorities of immigrants, including the need for safe and welcoming spaces, deportation planning, transportation, access to legal representation, public safety, access to the police, and accompaniment to places where they might be vulnerable to arrest.

- Prioritize pastoral service to immigrants and their families; fully incorporate them into all faith institutions, ministries, and programs; and educate nonimmigrant members and the broader public on the immense challenges facing immigrants.

- Identify, collect, disseminate and implement best pastoral practices for accompanying and supporting deportees and their families at all stages of the removal process.

- Advocate for the generous exercise of prosecutorial discretion; humane enforcement policies that prioritize family unity and cohesive communities; expanded legal avenues to regularized status; and strong citizenship policies.

\section{The Trump Administration's Immigration Agenda}

The CRISIS Study (Catholic Removal Impact Survey in Society) examines the Trump administration's immigration enforcement polices, which both build upon and break from the past. The administration has built upon restrictive laws, particularly the Illegal Immigration Reform and Immigrant Responsibility Act of 1996 (IIRIRA) (Kerwin 2018). It has also benefited from a wellfunded, multipronged enforcement system that has emerged over multiple administrations and Congresses (Meissner et al. 2013). In 2002, the Immigration and Naturalization Service (INS) - which was tasked with both providing immigration benefits and enforcing the law - had a $\$ 6.2$ billion budget (DOJ 2002, 106-07). A decade later, the combined budgets of the two major Department of Homeland Security (DHS) enforcement agencies, Customs and Border Protection (CBP) and Immigration and Customs Enforcement (ICE), equaled \$17.6 billion (DHS 2012, 85, 99), 
an amount that did not include funding for the adjudication of requests for immigration benefits or the significant other federal, state, and local expenditures on immigration enforcement. In fiscal year (FY) 2017, the enacted budgets for CBP and ICE increased to \$21 billon (DHS 2018, 29, 36). The administration is seeking $\$ 25.5$ billion for these agencies in FY 2019 (ibid.).

Unlike past administrations, the Trump administration has set sweeping, politically symbolic immigration enforcement goals such as gaining "operational control" of the border defined as "the prevention of all unlawful entries." ${ }^{8}$ Among other steps that would add to the undocumented population, it has sought to terminate the Deferred Action for Childhood Arrivals (DACA) program and revoke Temporary Protected Status for large national groups (Kerwin 2017).

In addition, it has terminated legal admission programs (like the Central American Minors program), cut refugee admissions to historically low levels, and endorsed legislation that would drastically slash legal immigration overall (ibid.). Most recently:

- US Citizenship and Immigration Services (USCIS) issued a proposed rule that would block legal migration for immense numbers of low-income immigrants deemed likely to become "public charges." ${ }^{\prime 9}$

- The administration has laid the institutional groundwork to denaturalize large numbers of US citizens (Wasem 2018).

- The president has announced plans to issue an executive order intended to end birthright citizenship for the US-born children of noncitizens, including undocumented immigrants (Lillis 2018).

These developments have engendered pervasive insecurity in immigrant communities.

Despite the president's repeated statements about a lawless, out-of-control border, the administration came into office following a multiyear period of steep decreases in illegal entries (particularly from Mexico) and in the US undocumented population (Warren and Kerwin 2015, 82-83, 86-89). Annual migrant apprehensions - a principal metric of illegal entries for INS and DHS - remain at less than one-quarter of their historic highs. However, they have dramatically increased between the administration's first and second years in office (CBP 2018), driven by the epidemic of violence, impunity, and poverty in Central America's Northern Triangle states, which has uprooted hundreds of thousands of families and unaccompanied children.

Studies suggest that significant reductions in US undocumented workers, who constitute 5 percent of the US labor force (Passel and Cohn 2016), would be economically disastrous. The undocumented work in large numbers in the leisure and hospitality, construction, professional and business services, manufacturing, wholesale and retail trade industries, and other services industries, and at disproportionately high rates in the agricultural, forestry, fishing and hunting, construction, and leisure and hospitality industries (Edwards and Ortega 2016, 6). The removal of

8 Border Security and Immigration Enforcement Improvements, Exec. Order No. 13767, 82 Fed. Reg. 8793 (Jan. 25, 2017).

9 Inadmissibility on Public Charge Grounds, 83 Fed. Reg. 51114 (proposed Oct. 10, 2018). 
these workers would lead to immense short- and long-term losses to these industries and, by one estimate, would reduce cumulative gross domestic product by $\$ 4.7$ trillion over 10 years (ibid., 11-13, 16).

"I am a teacher in my country [El Salvador], and at that time they were killing teachers. I was working in a school where one of my students who was six years old had a brother who belonged to a gang. Something happened with the child, and the mother came and threatened me. She said, 'If you continue to behave like that with my son, l'll see you outside. My son is in the M.S. [Mara Salvatrucha], and we will be waiting for you there.' I was scared every time I left school."

— Undocumented woman with deportation order, wife and mother of US citizen child

The Trump administration's enforcement strategies represent a break with past administrations, which recognized the need to prioritize certain immigrants (but not others) for arrest and removal (Kerwin, Meissner, and McHugh 2011, 15-16). As a rule, no law enforcement agency can pursue every offense committed within its jurisdiction. Smart law enforcement requires strategic, mission-based judgements on the most impactful mix of crimes to target. Ineffective agencies, in turn, fail to set meaningful priorities and squander their limited resources. Attorney General Jeff Sessions' directive to prosecute all illegal entries at the US-Mexico border (Office of the Attorney General 2018), for example, will almost certainly divert resources from the investigation, arrest, and prosecution of more severe and consequential crimes like human trafficking, illegal drug smuggling to the United States, and illegal firearms trafficking and bulk cash smuggling to Mexico and Central America. These crimes foster the conditions that uproot migrants and drive them to US borders.

The Obama administration deported historically unprecedented numbers of immigrants. They also set priorities for the exercise of discretion at all stages of the enforcement process. DHS Secretary Jeh Johnson released agency-wide policy guidance "to inform enforcement and removal activity, detention decisions, budget requests and execution, and strategic planning" (DHS 2014). The Johnson memorandum established three tiers of enforcement priorities. The highest tier comprised noncitizens deemed a threat to national security, unlawful entrants arrested at the border, criminal gang members and participants, convicted felons, and "aggravated felons." The second-highest priority included those convicted of three or more misdemeanors or one significant misdemeanor, certain unlawful entrants or re-entrants, and persons deemed to have abused visa or visa waiver programs. The third priority consisted of noncitizens issued a final order of removal.

The memorandum also allowed DHS officers to consider a range of factors - which militated against arrest and removal - in individual cases that would otherwise fall within its enforcement priorities. These included length of time in the United States, family or community ties, military service, and humanitarian considerations.

The Obama administration exercised discretion in a more structured way by creating the DACA program, which offers work authorization and a temporary reprieve from removal for select 
undocumented persons brought to the country as children. It also attempted to implement a similar program, Deferred Action for Parents of Americans and Lawful Permanent Residents (DAPA), which was enjoined in court and later terminated by the Trump administration. The administration publicly defended DACA, DAPA, and its enforcement priorities based on its finite enforcement resources. However, these initiatives also recognized the severe consequences of removing long-term residents, the lack of mens rea ${ }^{10}$ by persons brought to the United States as children, and countervailing family, economic, and rule of law interests implicated in select cases.

"I now worry about myself. Given everything that is happening, and as the president said, there are no priorities anymore. It does not matter if we are or are not criminals. He wants to throw us all out."

- Sister of deported immigrant

The Trump administration has taken a different tack. In its first week, the administration set such broad enforcement "priorities," covering, for example, "all removable aliens" and all who committed a "chargeable criminal offense" (including an immigration offense), that it failed to establish any priorities. ${ }^{11}$ Thus, its enforcement policies have targeted misdemeanants who illegally entered the country years in the past, as well as persons who were ordered removed, but allowed to remain in the country based on the strong equities in their cases (Rose 2017). ${ }^{12}$

"Both of them had been receiving stays of deportation. They had check-ins with ICE on a regular basis. Previously it had been once or twice a year, but then under the new administration, they were asked to come back a month later, two months later. There was always the fear that when they went back that would be the time that they would be detained, which is what happened. It was his second or third time going back when he was detained."

- Parish Hispanic Ministry Leader

CRISIS Study interviewees decried the Trump administration's elimination of what they characterized as the "priority system"; that is, its decision to target previously low-priority cases for arrest and removal. Many interviewees reported that they had previously led relatively secure lives and had come to assume that family members with clean records, US citizen children, and other dependents would not be deported. A number of deportees had routinely checked in with ICE for years before their deportation. The deportations of loved ones caught them off guard and significantly intensified fear in immigrant communities. In one such case, an immigration judge denied a removal waiver to a father whose child had a heart condition because the man had been driving without a license.

10 Mens rea (literally "guilty mind") refers to the knowledge and intent to break the law.

11 Enhancing Public Safety in the Interior of the United States, Exec. Order No. 13768, 82 Fed. Reg. 8799 (Jan. 25 , 2017).

12 These same equities, however, make removal a disproportionate punishment in many of these cases. 
The administration has used fear strategically to pressure the undocumented and their families to leave the country (self-deport) (Lind 2018). In the Trump administration's early months, for example, Thomas Homan, ICE's former Acting Director, repeatedly warned undocumented persons to "look over" their shoulders and insisted that they should be afraid (Wilkinson 2018).

The administration has also separated thousands of children from their parents at the US-Mexico border, initially arguing (inaccurately) that the policy violated no rights or laws, that it (in fact) had no other legal options, and that this tactic would deter families from seeking asylum in the United States (NPR 2018; Shuchart 2018).

"We took it lightly and thought it would never happen to us. We didn't make a plan. I used to be very active in the community. I helped and organized meetings where we discussed how to prevent and prepare for deportations just in case [Trump] would fulfill his word. But to be honest, I wasn't prepared."

- Mother of three US citizen children and wife of deported immigrant

DHS Secretary Kirstjen Nielsen further claimed that the policy was necessary to close the "functionally open border" and to remedy the failure of past administrations to enforce the law (New York Times 2018). Yet previous administrations, including the Bush and Obama administrations, vigorously enforced the law and invested substantially in border enforcement. The administration terminated this practice after it came under sharp attack as a form of child abuse, although hundreds of families still remain separated. Since then, it has issued a proposed rule that would permit the indefinite detention of children with their parents. ${ }^{13}$ It has also moved hundreds of children who arrived without parents from shelters to a large tent-city in West Texas (Fernandez and Dickerson 2018), and has entertained the idea of presenting detained families with a Sophie's choice: i.e., either to remain together in detention or move the children to a shelter where they could potentially be released to a family member or guardian (Miroff, Dawsey, and Sacchetti 2018).

While the administration and media have drawn significant attention to the US-Mexico border, apprehensions of those living in the United States (i.e., "interior" apprehensions, in contrast to arrests of recent border crossers) have increased during the Trump administration (ICE 2018, 1112). Many persons arrested at or near the US-Mexico border are attempting to return to their US families. ${ }^{14}$ "Interior" removals typically involve persons with long residence and significant equitable ties in the United States, many of whom later try to return. Not surprisingly, the normal intake process at the KBI aid center revealed a dramatic jump between 2016 to 2018 (from 43 to 78 percent) in deportees who reported having been separated from their families after living in United States.

13 Apprehension, Processing, Care, and Custody of Alien Minors and Unaccompanied Alien Children, 83 Fed. Reg. 45486 (Sept. 7, 2018).

14 Eight CRISIS Study respondents had been deported more than once. 


\section{Cristina's Story}

Cristina (not her name) has five US citizen children between the ages of eight and 16. For 18 years, she lived with her husband in the United States. Immigration officials arrested her husband at an immigration checkpoint as he was driving home from work with four co-workers.

Her husband - who awaits deportation in an immigrant detention center - was found eligible for a family-based visa based on a petition filed by his brother nearly two decades earlier. However, he remained mired in a multiyear visa backlog. While in detention, he had been scheduled for his "biometrics" appointment, part of the process for securing a visa that involves the collection of fingerprints, a photograph, and other data. The immigration judge, however, refused to release him to attend the appointment on the grounds that he had been driving without a license and thus, presented a danger to the community.

Cristina says: "My children feel like their father chose to leave them. They are upset. The oldest one feels the weight of the responsibilities. He knows he will have to work to help out. The second oldest knows that he will have to be in charge of his siblings while his brother and I work." She adds: "I am afraid because the government has all my information. They know I am here alone and that I am an [undocumented] immigrant. I only trust in God. I know He is with me and that nothing will happen to me because of the children."

Cristina does not drive. "Nowadays," she says, "I work with another girl cleaning houses, but I only earn $\$ 25$ to $\$ 30$ a day." She reports that her family never before requested government assistance, but will now need to apply for food stamps. Her husband has asked Cristina to sell everything and return to Mexico, but her children do not want to leave. "I am between the two," she says.

Multiple studies have documented deportation's devastating emotional, physical, and behavioral consequences on children and adolescents. ${ }^{15}$ Children suffer "depression, anxiety, fears of separation, social isolation, self-stigma, aggression, withdrawal and negative academic consequences" (Zayas and Cook-Heffron 2016).

"My children's grades dropped. They became rebellious. They miss their dad. They couldn't assimilate the many changes they were facing. I did not use to work, but now I do. I work from 5 a.m. to 10 p.m. I don't see my children. Sometimes they have to help me to cook because I can't due to work. They are also seeing psychologists now."

- Mother of three US citizen children and wife of deported immigrant

Of the CRISIS Study respondents, 76 percent reported that their children had experienced psychological problems, ${ }^{16} 48$ percent that their children were experiencing difficulties in school, and 19.6 percent that their children felt "less safe." 17

15 CBP has also separated families during the apprehension and removal process (Danielson 2013, 10-15).

16 This rate refers to respondents with a spouse or domestic partner.

17 These findings refer to families both in the United States and Mexico. 
Many CRISIS Study interviewees said that their children needed psychological assistance and counseling. After their parent's detention and deportation, many children demonstrated rage, aggression, fear, depression, distractedness, confusion, and uncertainty about their futures. One of the mothers reported that her 12-year-old son had attempted suicide the day of his father's scheduled deportation. Several mothers reported feelings of depression.

CRISIS Study interviewees reported that children feared their family members would be deported while they were at school. As a result, they lost interest at school and their grades suffered. Some related that their children had shut themselves off from friends and lost interest in normal activities. Some isolated themselves in their bedrooms after school.

"Children watch the news and don't want to go to school because they are afraid that their mom or dad won't be there when they get home."

- Parish ministry leader

One interviewee whose brother had been deported recounted that children at school had taunted her son, telling him that she and her family would be sent back to Mexico. Children believe, she said, that even US citizens of Mexican ancestry can be deported.

As this case illustrates, the negative effects of deportation were not limited to the children of deportees. Children with deported aunts, uncles, and cousins also suffered. Nor were these effects confined to young children. Interviewees explained how older children tried to assume the financial and emotional responsibilities of deported parents. In particular, they sought to become family breadwinners, to obtain a driver's license in order to transport family members, and one even took steps to become the guardian of younger siblings.

"My 14-year-old son wants to take on his dad's responsibilities. Now he wants to go to work with his uncles. He asked them for work, but he doesn't have the physical ability or age to work in construction, which was his dad's occupation."

- Mother of three US citizen children and wife of detained immigrant

Interviewees also explained the administration's deleterious influence on local immigrant integration initiatives. In 2015, for example, the Palm Beach County Sheriff and Commissioners had tentatively agreed to accept consular identification cards (IDs) as valid identification. However, thousands of undocumented immigrants could not access this type of ID and thus remained at risk of arrest for driving without a license. In response, advocates sought to implement a community ID program in Palm Beach County. In early 2018, the County's Criminal Justice Commission endorsed the community ID proposal. The proposal, however, came to a halt after the Palm Beach County Commissioners and Sheriff raised concerns about losing federal funding and potential fraud. The community ID retains the support of West Palm Beach's mayor, but will not be accepted as a form of ID by the Sheriff's office. Interviewees also noted intensified police activity due to the president's frequent visits to the area. 


\section{Findings from the CRISIS Study}

\section{Length of Residence, Legal Status, and Homeownership}

Most US undocumented immigrants have made their lives in the United States. Of the nearly 11 million US undocumented residents, 1.9 million have lived in the United States for at least 20 years, 1.6 million for 15 to 19 years, and 3.1 million for 10 to 14 years (Warren and Kerwin 2015, 99). Nearly 3 million undocumented residents arrived at age 15 or younger (Kerwin and Warren 2017, 321).

"When we come, we think we will be here for only two or three years. Look at me now, I have been here for more than half my life."

- Mother of three US citizen children and wife of deported immigrant

CRISIS Study survey respondents had longstanding and deep connections to the United States. On average, respondents had lived in the United States nearly 20 years. More than one-half (56 percent) first entered the country as children (below age 18), and 21 percent below age $10{ }^{18}$ Likewise, several interviewees had arrived as children, including one who entered with his family at age two.

\section{Chart 1. Length of US Residence of Deportees}

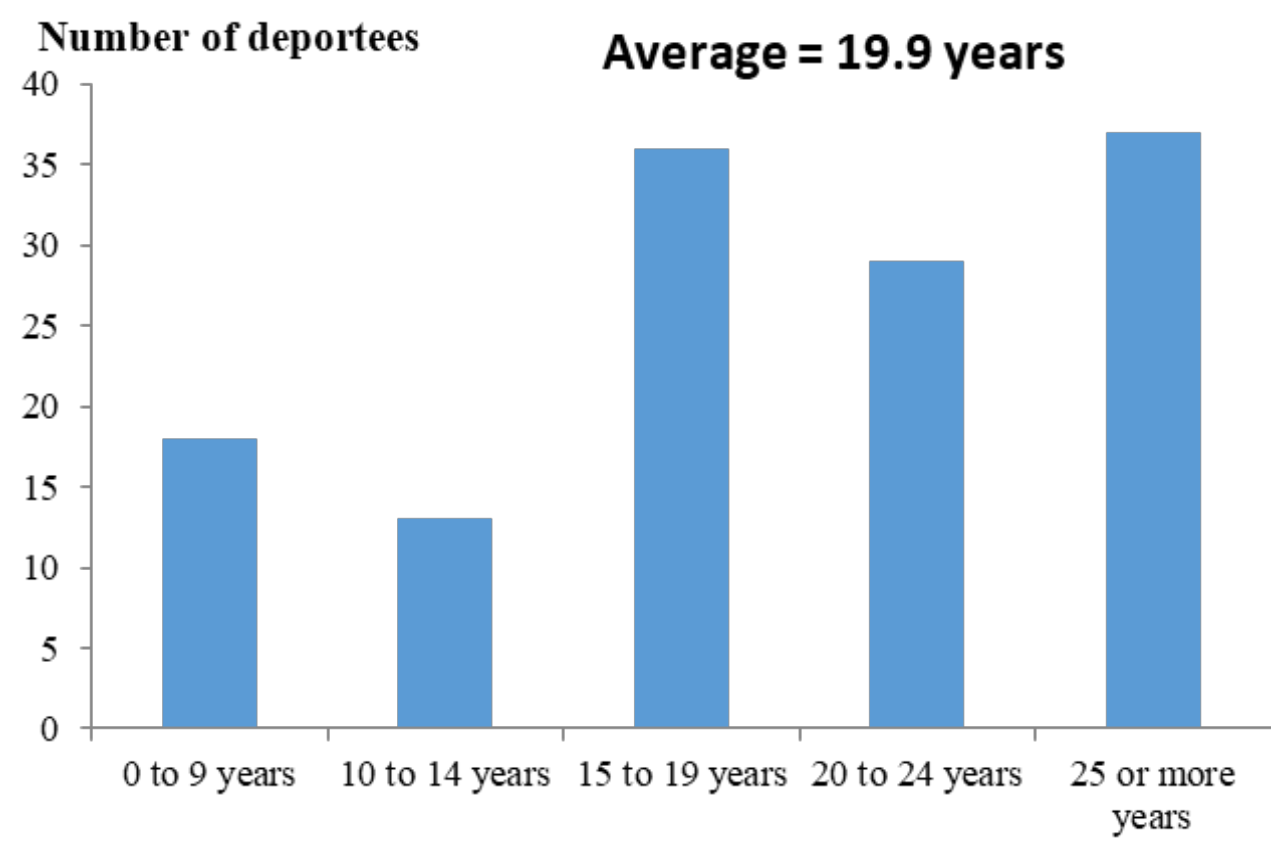

Source: CRISIS Study, January-May 2018.

A high percentage of respondents (38 percent) reported having had legal status in the United States prior to their deportation, and 14.3 percent were lawful permanent residents. ${ }^{19}$ Twenty-

18 Some respondents had entered the United States more than once.

19 This phenomenon dates to IIRIRA. IIRIRA expanded the grounds of removal and restricted relief from removal based on long residence in the United States and other equitable ties to the country. Its implementation, starting in 1997, triggered increased deportations of long-term residents, including LPRs, with US families, for committing relatively minor crimes often in the distant past (Kerwin 2018). 
six percent were homeowners. ${ }^{20}$ Fifty-two percent participated in church activities, 34.1 percent regularly attended church services, and 9 percent participated in community organizations.

\section{Divided and Impoverished Families}

CRISIS Study respondents had an average of more than three children. Seventy-eight percent of respondents had US citizen children and nearly 4 percent of respondents had children who were DACA beneficiaries. ${ }^{21}$ The average age of their children living in the United States was 14.9, and 33 percent were 10 years old or less.

"My children [who are DACA recipients] are in limbo on a daily basis without knowing what's going to happen ... I'm not in the system, l've been here 18 years and I'm not in any criminal system. But my children are in the system and if they say tomorrow 'Okay, DACA's over, you're all criminals,' they'll do it. They are holding my children hostage."

— Undocumented activist and mother of two DACA recipients

Nearly 63 percent of respondents were married or in a civil partnership. Of these, 42 percent had a US citizen spouse or domestic partner.

These findings roughly correspond to an analysis of 2012 data from the Mexican Government's Survey of Migrants at the Northern Border - Returned Migrants (EMIF-Norte), which found that 61.4 percent of deportees who had spent at least one year in the United States had a child in the United States and an equal percent had a US resident spouse (Danielson 2013, 18-19).

\section{Chart 2. US Family and Other Ties of Deportees}

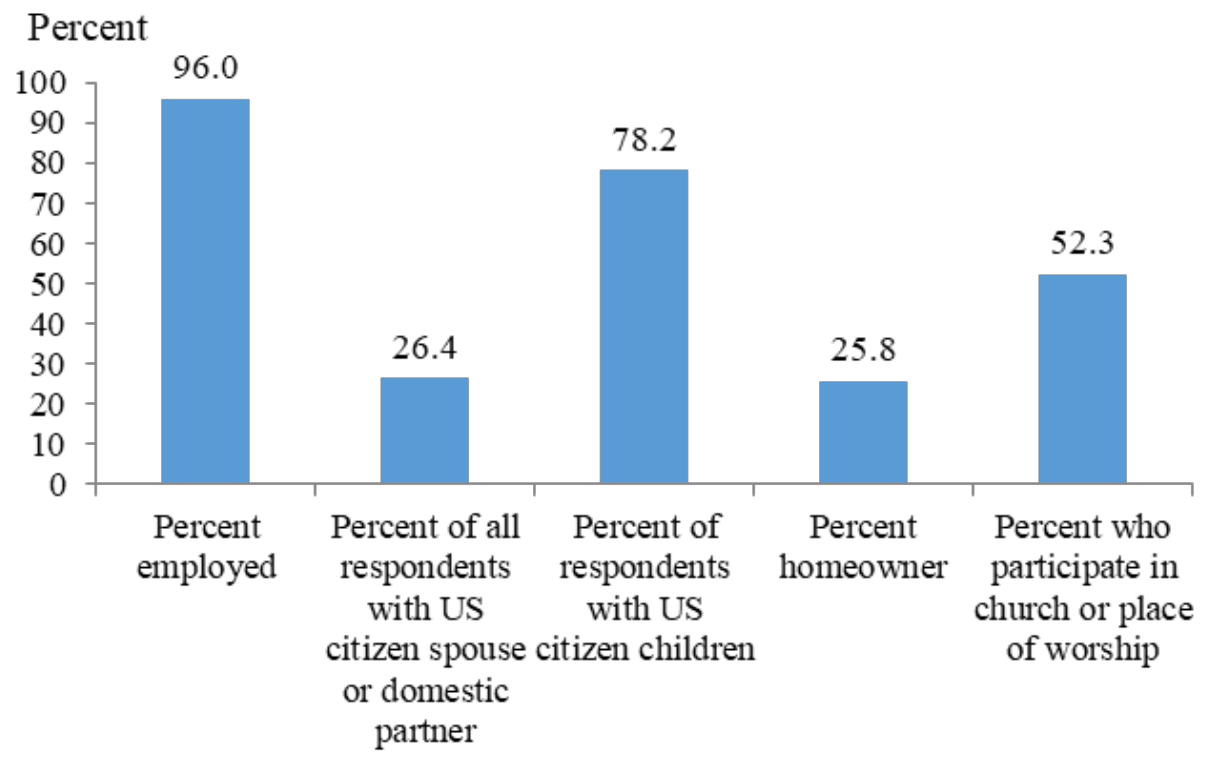

Source: CRISIS Study, January-May 2018.

20 A CMS study found that 23 percent of mixed-status households - those with at least one US citizen and one undocumented resident - had mortgages (Warren and Kerwin 2017, 6).

21 Overall, the US undocumented population includes 3.9 million parents of US citizens and LPRs, and roughly four million with a close family relationship to a US citizen or LPR that qualifies them for a visas, but who languish in backlogs (Kerwin and Warren 2017, 320-21). 
The interviews underscored the trauma that deportation works on families. Many interviewees reported experiencing depression and visiting therapists after their loved ones were deported. Children and adults recounted their fear and uncertainty about the future at news of deportations. Several reported being accosted at home by armed, uniformed ICE officers who were searching for one of their relatives. These experiences traumatized children and led adults to fear leaving the house, lest they be pursued by ICE.

\section{Rosa's Story}

In 2010, Rosa (not her name) left her home to take her usual morning walk around her neighborhood. As she was leaving, a few cars surrounded her outside her house. Armed men got out, telling Rosa that she had to return to Mexico because she was undocumented. The men allowed Rosa to say goodbye to her three US citizen children - ages six, eight, and 12 - who were in the house, getting ready for their last day of school.

Rosa entered the United States in 1997 on a tourist visa. Her brother, a US citizen, filed a familybased visa petition for her in 2001, which was approved, but placed her in a multiyear visa backlog. After her arrest, Rosa was detained for 23 days. Ultimately, immigration officials released her, but detained and deported her husband to Mexico instead.

Six months after being released, the government told Rosa she would have to leave the country. Yet in 2011, Rosa's parish and other organizations launched a campaign to stop her deportation. The campaign led immigration officials to grant her a temporary reprieve from deportation. She was then able to renew her work permit and stay of removal every year between 2011 and 2017. During this period, she worked from 5 a.m. to 7 p.m. and family members helped to pick up and drop off her children from school.

In her 2017 check-in, Rosa was told that, due to new instructions issued by the Trump administration, she would have to leave the country. At the time, Rosa was supporting her oldest daughter who was in college. She was also planning her second daughter's quinceañera. She decided to take her two youngest children with her to Mexico, although they wanted to remain in the United States. Her oldest daughter stayed in the United States to attend college. Rosa reports that her children have had many difficulties at school in Mexico due to the language barrier and culture shock.

Rosa's oldest daughter says that "not only did (my mom) get deported but both of my siblings also went away. In a way, I lost my family." Her mother's deportation was scheduled during the week of her final exams. Afterwards, the daughter found someone to rent the family's house, threw away most of their furniture, put some other belongings in storage, and returned their car to the dealer. She now lives with her uncle and waits tables, often taking extra shifts to help support her family in Mexico. She hopes to petition for a visa for her parents when she turns age 21.

Many children who left the country with their deported parents have experienced difficulties in adjusting to their new lives and want to return to the United States. Some blame their parents for their predicament.

The threat of deportation is pushing some immigrants to work additional hours and to prepare for possible family separation. One interviewee reported that a local immigrant leader "has two 
kids and he now works as a laborer during the day and works renovating restaurants at night because he wants to save up money in case he's deported. So not only his kids do not see him, but he also had to stop his volunteering." Interviewees also noted that some immigrants have opted not to buy homes or start businesses for fear of deportation.

"In terms of economic impact, all the immigrants I work with work really hard and if they weren't around, I know Palm Beach would not look like it does in terms of the landscaping industry."

- Parish organizer

Prior to their deportation, 96 percent of CRISIS study respondents were employed, including 40.6 percent in construction and 13.5 percent in food services. On average, they had worked steadily in their jobs for nearly 10 years, earned roughly $\$ 2,800$ per month, and had fewer than 9 years of education.

Survey respondents (deportees), who have lost their jobs and income, are now indigent. On average, they had the equivalent of $\$ 142$ with them at the time of their deportation. High rates of respondents reported needing assistance with employment (78.2 percent), finances (68.4 percent), housing (56.4 percent), emotional problems (56.4 percent), and social integration (54.9 percent) needs. Their families are also faring poorly. Most reported that their spouse/partner in the United States did not have enough money to support their children (74 percent) or to live on (63 percent). Not only do the families of deportees lose vital income streams, but some bear the costs of deportation-related legal fees and struggle to pay loans they took to migrate to the United States.

\section{Chart 3. Difficulties Faced by the Family Members of Deportees}

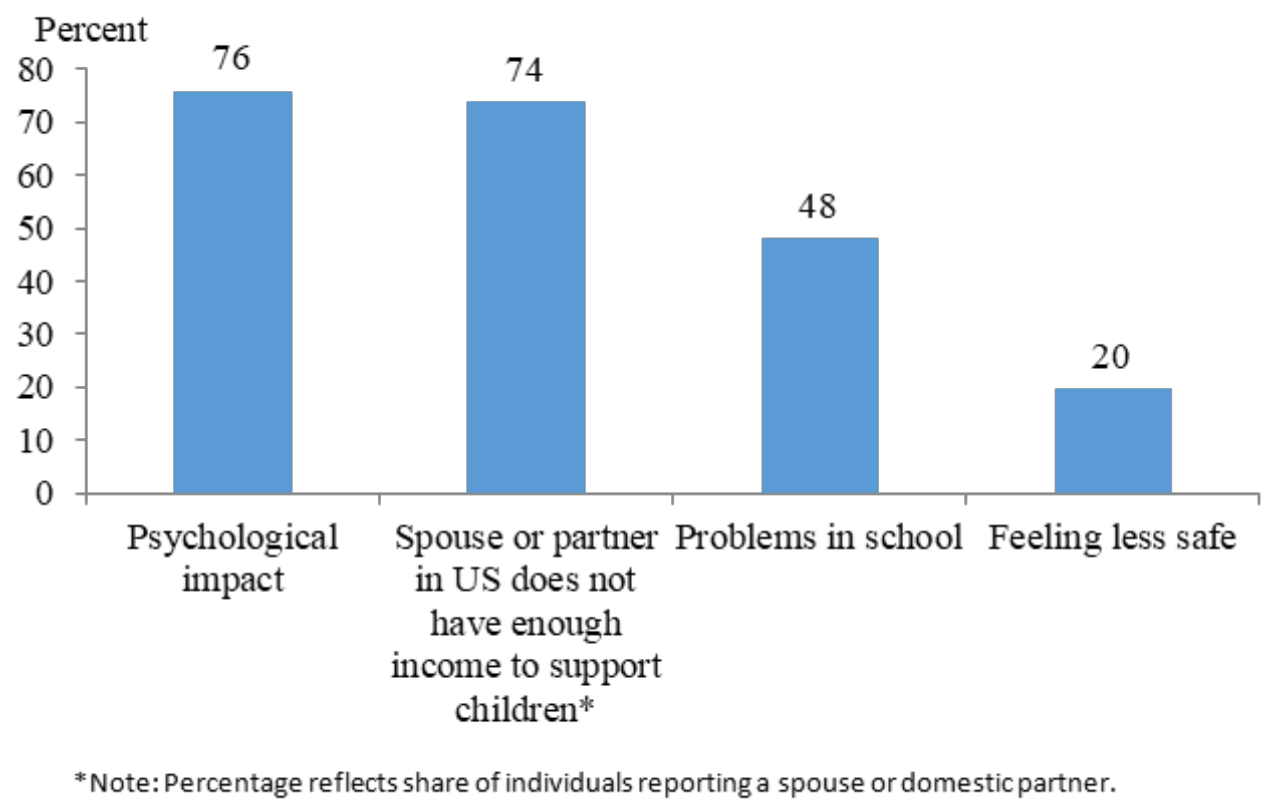

Source: CRISIS Study, January-May 2018. 
While the children of deportees face particular difficulties, survey respondents reported that a range of other close family members also depended financially on them prior to their deportation. Nearly two-thirds (63.4 percent) of married or partnered respondents reported having financially dependent spouses, 72 percent had dependent mothers, 57 percent dependent fathers, and 26 percent dependent siblings.

\section{Chart 4. Dependents of Deportees}

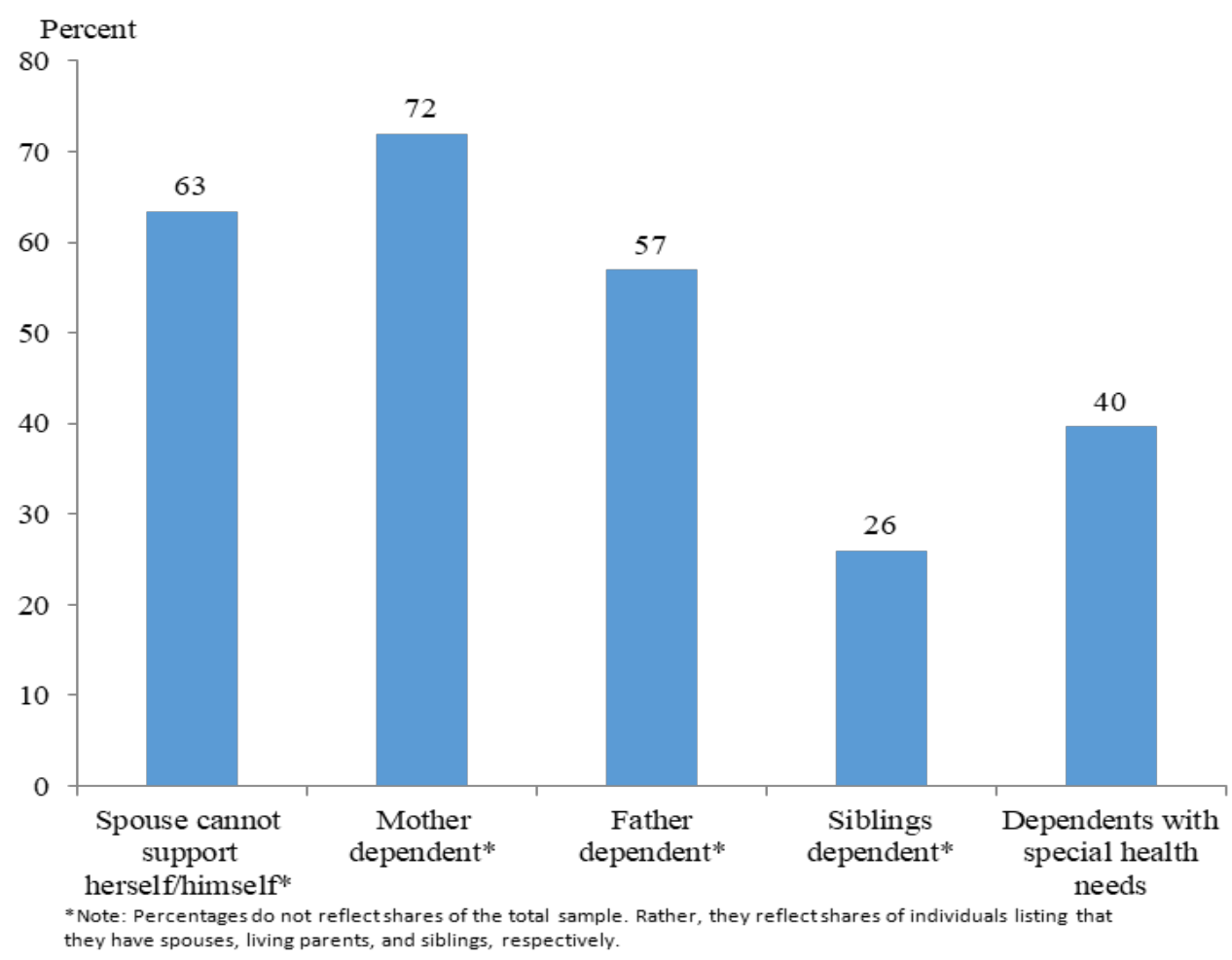

Source: CRISIS Study, January-May 2018.

Furthermore, 40 percent of survey respondents reported having dependents with special needs. ${ }^{22}$ These included pregnant wives (one with twins), children with autism, a daughter with brain cancer, and mothers and fathers with cancer. Another noted that, since her brother's deportation, she has had to work more to support her mother in Mexico who has cancer and needs blood transfusions. In addition, interviewees said that when parents have to work more under these circumstances, children are frequently left alone at home and can become bored and depressed.

"It was easier when my brother was here because we supported each other and sent money to my mother so that she could do everything she had to. Now my mother is not doing everything she once did with respect to medicines.... It is hard for me to help her in that way." 
"Every time we talk about this topic, it hurts and we cry. My 16-year-old daughter will probably go to study to the United States because she is having difficulties with Spanish and cannot keep up with advanced classes in Spanish. Her entire life she has thought in English. My children told me I did not love them because if I had, I would have left them where they were happy."

- Deported mother

Overall, 3.3 million US households contain at least one US citizen (typically a child) and an undocumented resident (often a parent) (Warren and Kerwin 2017, 4). These mixed-status households include 5.7 million US born children under the age of 18 . By one estimate, removing their undocumented members would reduce their median household income from $\$ 41,300$ to $\$ 22,000$, push millions of families into poverty, and conservatively reduce the income available to support their US-born children until maturity by \$118 billion (ibid., 5-6). ${ }^{23}$

"He wants to return to the US because he is not doing well in Mexico. There is no work, and sometimes it can be dangerous where he lives."

- Mother of three US citizen children and wife of deported immigrant

\section{Plans to Return to the United States}

Most survey respondents entered as children, lived in the United States for long periods, and enjoyed strong family, social, and economic ties to the country. Forty-five percent of respondents identified only a little or "not at all" with their country of birth. Only 35.4 percent reported feeling "safe" since their deportation, which may reflect the high levels of violence in Mexico, the many years deportees have lived outside their country of birth, and their lack of financial resources.

"Folks who are deeply embedded in this community get ripped away from it and now they are in a country of origin that they haven't been to in over a decade. They do not really have social capital there anymore. I have heard from one of them, who has expressed a fear for his safety because folks around him knew that he had been recently deported from the US and so he must have capital, money, or networks in the US. He feared that he would be targeted."

- Parish Hispanic Ministry Leader

Thus, it comes as little surprise that nearly three-fourths (73.5 percent) plan to return to the United States, roughly one-fourth as soon as possible. These findings suggest that deterrence measures (like removal) do little to dissuade deportees who view the United States as their home from attempting additional crossings (Slack et al. 2015, 114-16).

23 This estimate assumes that just one-third of the US-born children of deported undocumented residents would remain in the United States following the deportation of a parent. 
"She wants to return 100 percent. She says 'if they tell me tomorrow that I can return,' she'd return without thinking twice because she has, and has always, thought that the best education for her children is here. She said that her kids come first. Where her children are well, she's well."

- Sister-in-law of deported immigrant

\section{The Criminalization of Deportation}

Immigrants, particularly the undocumented, commit crimes at lower rates than natives and high levels of immigration are associated with lower rates of violent and property crime (Nowrasteh 2018; Rumbaut 2018). Nonetheless, the Trump administration has regularly conflated immigrants with violent criminals, publicized crimes committed by noncitizens, and established the ICE office of Victims of Immigration Crime Engagement (VOICE) to support and magnify the voices of "crime victims and their families who have been affected by crimes committed by individuals with a nexus to immigration." ${ }^{24}$

Nonetheless, the Trump administration has mostly deported persons who either have no criminal records or are nonviolent offenders, including for traffic and immigration offenses. ${ }^{25}$ This trend has accelerated in 2018. An analysis by David Bier of the Cato Institute of ICE removals from FY 2009 to FY 2017 found that 47 percent had no convictions, and high percentages of those with criminal records had committed immigration violations, traffic offenses, or had driven under the influence (DUI) (Bier 2018). ${ }^{26}$ Twelve percent of "criminal aliens" had committed crimes of violence (ibid.). The first nine months of FY 2018 witnessed a sharp increase in arrests and removals of noncitizens without criminal records, compared to the same period in FY 2017, and many of those removed on criminal grounds were convicted of low-level offenses (Sedensky 2018).

The CRISIS Study's findings illustrate this pattern. Nearly one-half of survey respondents reported that they had not been convicted of a crime prior to their deportation. Of the 37 respondents (51.4 percent) who reported having been convicted of a crime, ${ }^{27}$ more than one-third (35.1 percent) had been convicted of a traffic or immigration offense, 21.6 percent of a drug-related crime (including possession), and another 21.6 percent of a violent crime. ${ }^{28}$ Seventeen percent of respondents reported having served more than a year in jail or prison prior to their deportation.

24 ICE, "Victims of Immigration Crime Engagement (VOICE) Office," https://www.ice.gov/voice.

25 Although widely used, the term "criminal alien" is deceiving in that everyone in immigrant detention has already served whatever criminal sentence they may have received and many detained immigrants have never been convicted of a crime. In addition, "criminal alien" detainees and deportees have long included high rates of immigration and traffic offenders (MRS/USCCB and CMS 2015, 174-75; Kerwin and Alulema 2015, 346-47).

26 The Cato Institute study distinguished between violent crimes, property crimes, crimes with no victims, and crimes with possible victims. It characterized DUI as a crime with possible victims and, thus, did not group DUIs with traffic violations.

27 Only 72 respondents answered this question.

28 The CRISIS study classified these self-reported crimes based on the National Crime Information Center's (NCIC) uniform offense codes. 


\section{Chart 5. Time in Criminal Custody}

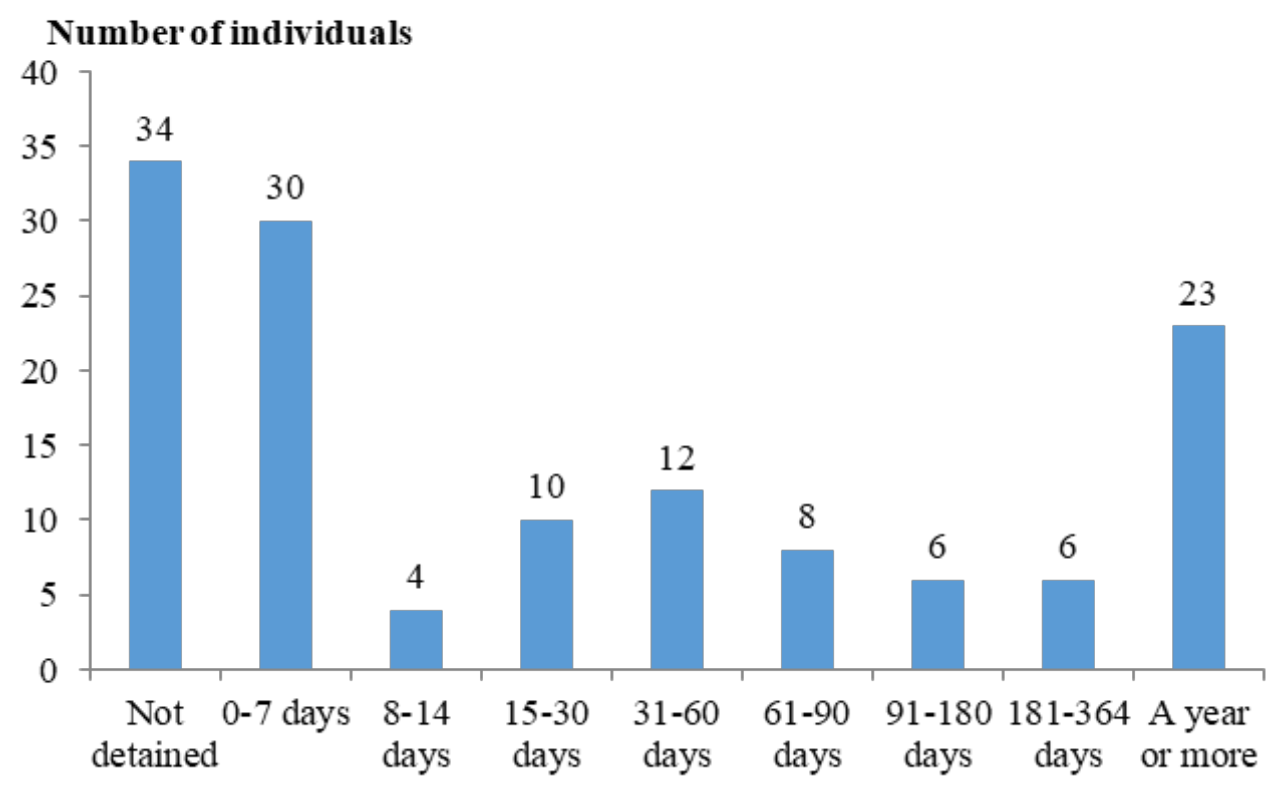

Source: CRISIS Study, January-May 2018.

A high percent of survey respondents (65.2 percent) reported that their deportation began with a police arrest. Nearly 30 percent reported being arrested by another agency before being transferred to ICE. Smaller numbers reported being apprehended by ICE (30.3 percent) and less than one percent by CBP. The arrests took place while respondents were driving (36.1 percent), at home (26.3 percent), at work (6 percent), and in jail (6 percent).

\section{Chart 6. Agency that Carried Out Arrest Leading to Deportation}

\section{Percent}

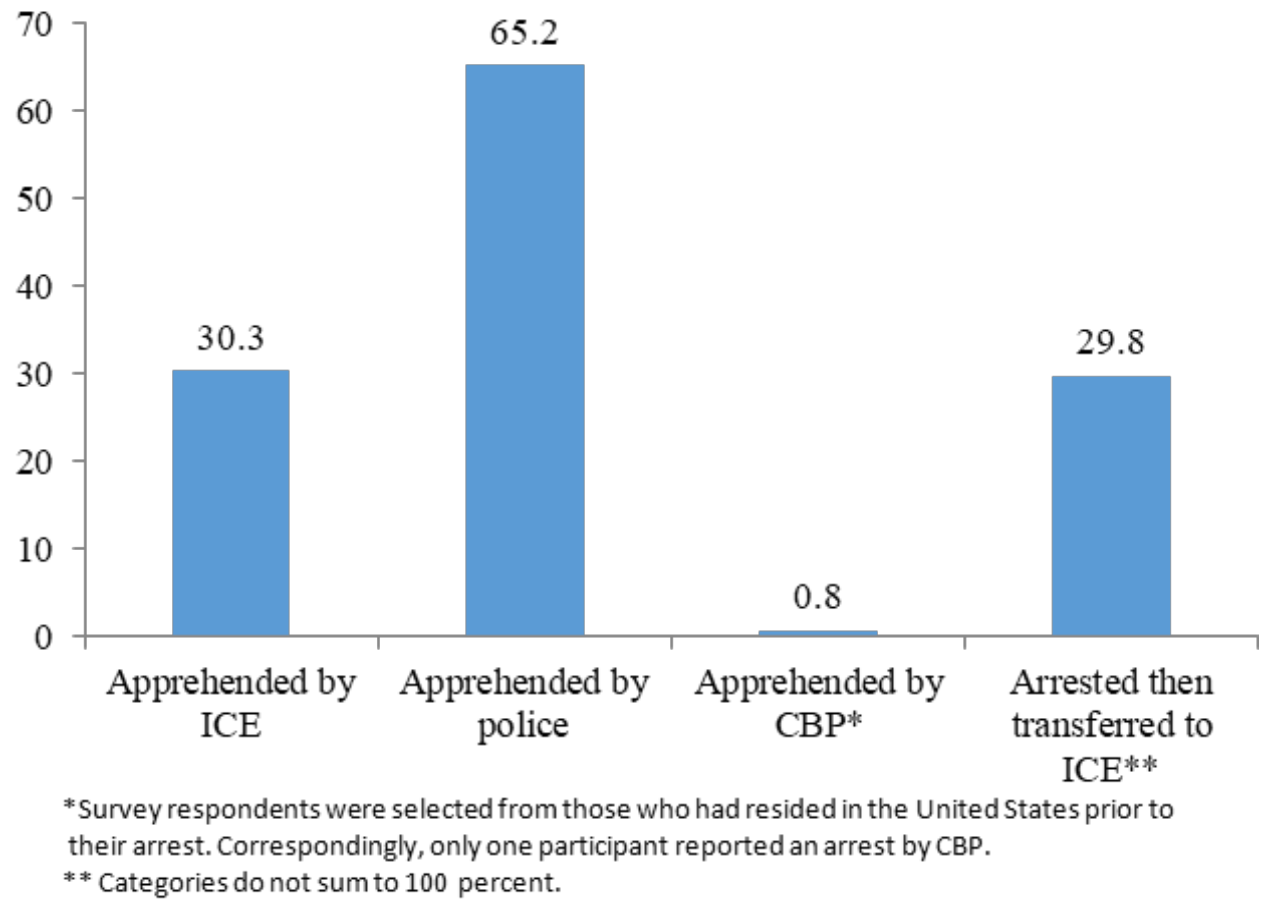

Source: CRISIS Study, January-May 2018. 
Several interviewees emphasized the greater police presence in their area following Trump's election. In Minnesota, interviewees noted that police often waited near offices that immigrants frequent to send money to relatives in other countries and that ICE had targeted language centers that hire native Spanish-speaking teachers. ${ }^{29}$ Many interviewees emphasized the increase in police arrests for traffic violations in their communities. Many also lamented the elimination of Obama-era enforcement priorities.

"We heard about people being stopped and arrested for driving without a license. We heard awful stories about people being pulled over on Interstate 95. There was a man at a parish that had his whole family in the car. They arrested him and then made the family call a taxi. They left all the groceries in the car."

- Parish organizer

According to interviewees, these practices led many undocumented immigrants to keep a low profile. In particular, they have reduced their local travel, which can translate into less work and reduced household income. In some areas, immigrants opt to walk or ride bikes to work. Other interviewees noted reduced attendance at Mass.

\section{Chart 7. Circumstances of Arrest}

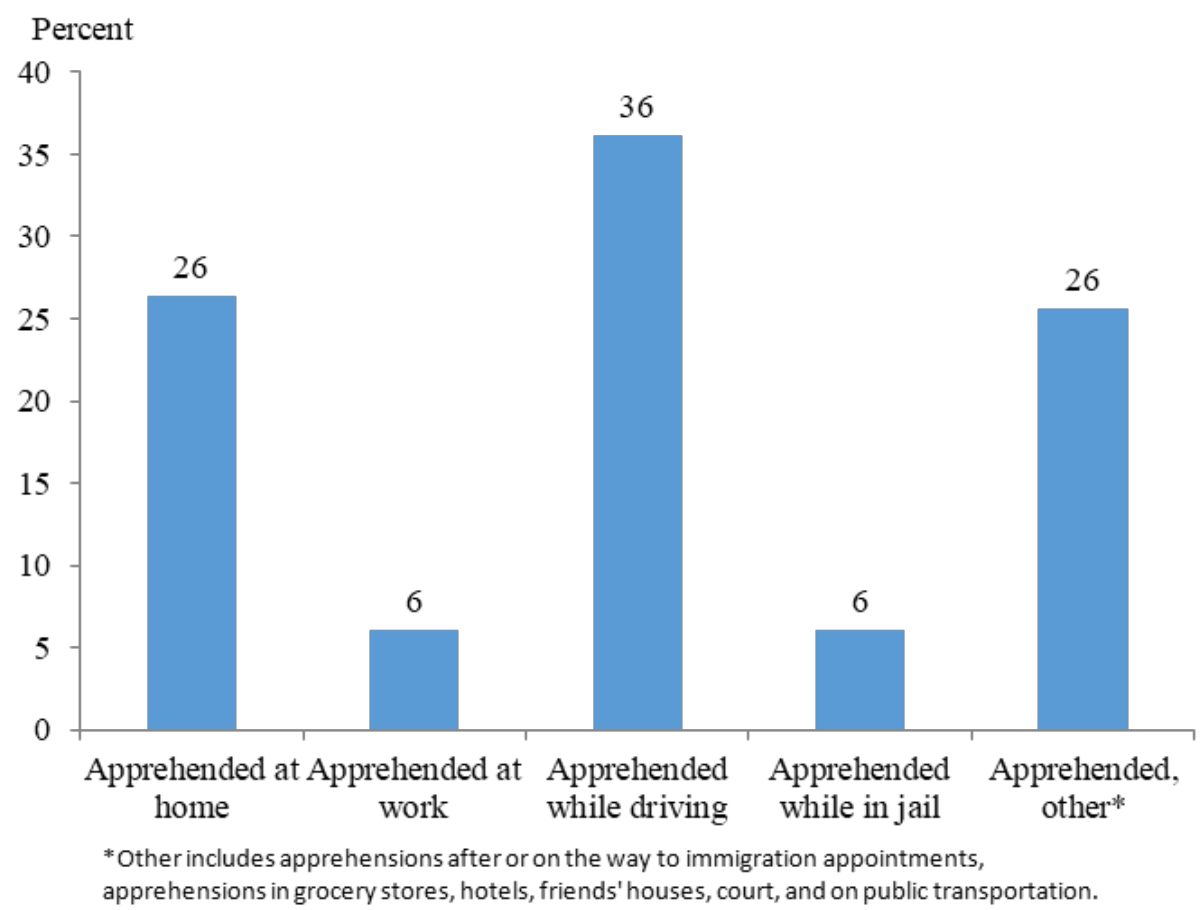

Source: CRISIS Study, January-May 2018.

The Trump administration has fully committed to immigration enforcement by state and local police, ${ }^{30}$ which ICE has long viewed as a "force multiplier." Yet police acting as immigration agents

29 One interviewee recounted that ICE waited outside a family's home for upwards of eight hours. Others noted that individuals have been arrested at a local mall, on Greyhound buses, and in trains.

30 Enhancing Public Safety in the Interior of the United States, Exec. Order No. 13768, 82 Fed. Reg. 8799 (Jan. 25, 2017); Border Security and Immigration Enforcement Improvements, Exec. Order No. 13767, 82 Fed. Reg. 8793 (Jan. $25,2017)$. 
in the normal course of their work can undermine public safety. This is a particular risk in Arizona (where most survey respondents lived) and in other communities where police have long worked hand in glove with CBP and ICE. If immigrant communities, for example, "perceive that police are enforcing federal immigration laws, especially if there is a perception that such enforcement is targeting minor offenders," they may begin to distrust the police and "become fearful of reporting crime or approaching the police" (HSAC 2011, 24). Moreover, police may engage in ethnic or racial profiling, or commit pretextual arrests for minor offenses that they believe will lead to deportation. In these circumstances, immigrants and their family members often avoid contact with the police so as not to risk deportation (Coon 2017, 654-57, 663).

\begin{abstract}
"I have a driver's license. One day I went with my friend to buy pizza. When I was turning a corner, a police car stopped me. I asked the policeman why he stopped me, but he asked for my license. He said my tail light didn't work. He told me to fix it and gave me back my license. He said I could leave and that it had been a routine check. I told my husband what had happened and he said the light worked fine. We went to check the tail light, and indeed it was working fine."
\end{abstract}

— US citizen sister of deported immigrant

CRISIS Study respondents spent an average of 96 days in immigrant detention. Thirty-one percent were detained seven days or less, 57 percent for 30 days or less, and 17 percent for more than six months. Nearly three-fourths (73.4 percent) reported having appeared before an immigration judge. The rest were presumably subject to reinstatement of removal or another form of summary removal (Kerwin 2018).

Chart 8. Time in Immigration Detention

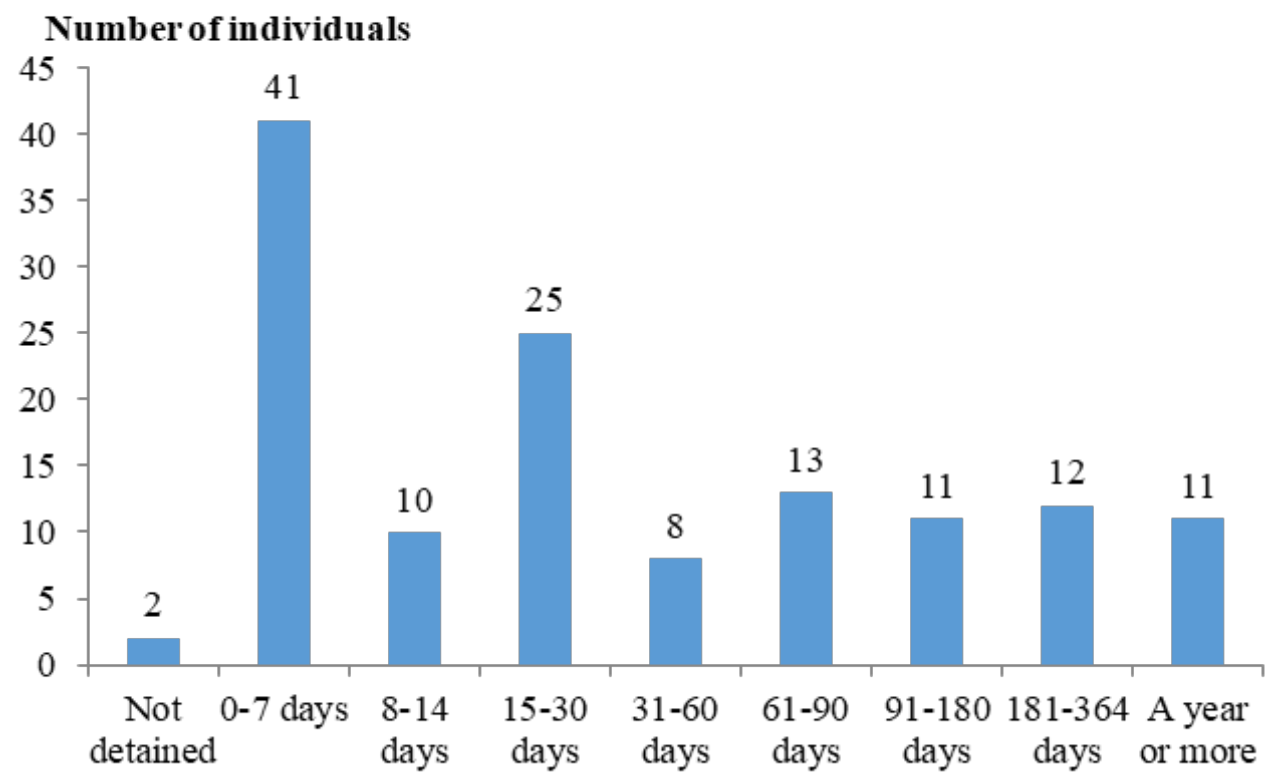

Source: CRISIS Study, January-May 2018. 
Several interviewees emphasized the poor treatment that detained family members received in detention centers. They reported on poor and inadequate food that left their relatives hungry even after meals, the failure of detention staff to prevent harassment by other detainees, and lack of mental health services. One interviewee reported that his detained son had been cutting himself, but rather than provide him with professional counseling and assistance, the detention staff put him in a straitjacket.

Interviewees also emphasized the lack of transparency in the detention and deportation process. They complained of struggling to locate loved ones in the detention system. Several reported that contact with detainees was limited to immediate family members.

Others reported that the government kept payments they had made that should have been returned to them. One woman said that she had never been reimbursed for posting bail for her brother who had been arrested by the local police, but not released from custody and (instead) handed over to immigration officials for detention and deportation. Another recounted that after she received a deportation order, USCIS had not reimbursed her for the fees she had paid to renew her work permit, which she never received.

Only 28 percent of survey respondents were able to secure legal counsel, a rate higher than that reported in more comprehensive studies on the legal representation of detainees (Eagly and Shafer 2015, 30-35), but still a decided minority. ${ }^{31}$

A similar pattern emerges regarding time spent in jail or prison. The largest group (25.6 percent) reported spending no time in criminal custody, the next largest (22.6 percent) zero to seven days, and the third largest (17.3 percent) more than one year.

\section{The Work of Faith Communities with Immigrants}

CRISIS Study interviews took place in three Catholic parishes. While the interviews mostly addressed the impact of deportation, they also spoke to challenges in the relationship of faith communities and their immigrant members in an era of escalating anti-immigrant rhetoric, growing numbers of arrests and removals of members, and an administration bent on large-scale deportations and sharp cuts in legal migration.

US faith communities increasingly view the treatment of immigrants as a major social problem, and a profound pastoral challenge as well. An intensive 20-month planning process, leading to the $V$ Encuentro of Hispanic / Latino Ministry for the Catholic Church in the United States, for example, highlighted the social, legal, and pastoral consequences posed by US immigration policies (USCCB 2018). For the undocumented and their families, these include:

- the constant fear of deportation;

- family separation;

- interference with life plans, like marriage and children;

- detention;

- lack of access to social benefits and to effective protections in the workplace;

31 Unrepresented detainees secure relief from removal at far lower rates than noncitizens who are not in custody or who have legal representation (Eagly and Shafer 2015, 49-51). 
- fear of reporting crime; and

- denigration by the press and public officials, including the president.

These realities lead to a sense of isolation and prevent immigrants and their families from fully participating in their communities. To faith communities, they represent an affront to human dignity.

CRISIS Study interviews provided a window on the pastoral challenges posed by deportations. First and foremost, deportations have torn apart the fabric of faith communities:

"At gatherings after mass or at the Our Lady of Guadalupe celebration, we would have everyone gathered together and having a good time and the names of the folks who have been deported always come up. It's always a lament that it's not the same without them here. We are talking about folks who have been here for and part of our community for $10,15,20$ years. They are deeply embedded in our community, and so when they are ripped from us, that hurts not only the one who is deported or their immediate family, but it's all of us. It's our whole parish community that hurts."

- Parish Hispanic Ministry coordinator

Deportation and the threat of deportation also negatively affect participation in church ministries and programs. "Whenever there's a public raid in the community," said one parish leader, "we see our numbers decrease at mass the following weekend because folks are afraid to leave their homes." The changed family dynamics affect even church sacraments and rituals. One interviewee described how a young parishioner sought to expedite her confirmation. She viewed this sacrament as akin to becoming an adult in the church, and "thought that if she was confirmed ... she'd get to keep her younger siblings if something happened to her mom." Another parishioner "was waiting to turn 16 so he could obtain his driver's license to drive his mom so she could move around without much fear."

For their part, immigrants view their faith communities as potentially safe, welcoming, and supportive places at a time of hostility and profound threats to the integrity of their families. CRISIS Study interviews revealed that some families received significant support from their parishes. One parish had organized discussion forums which aimed to help members plan for and talk to their children about deportation. Parishes also fostered connections with legal services agencies and provided referrals for families in need.

Interviewees noted that their parish provided a variety of services to their families, including phone cards, sending others to their homes to pray, recommendation letters, and monies for lawyers' fees and sometimes bail. The parish's Hispanic Ministry program had also organized a series of gatherings that allowed immigrants to interact with local police. At these events, police officers expressed surprise that undocumented immigrants might be arrested while driving children to school.

At the same time, some interviewees expressed disappointment with their parish's and (more broadly) the Catholic Church's response to their situation. Some raised concerns relating to the lack of vocal leadership and support from diocesan leaders. One explained: "Here the Church is not anti-immigrant, but it's not pro-immigrant either." Another spoke about the Church's silence during the DACA program and during a campaign for a community ID card. Another said that 
her local church had denied her a letter of reference when her husband was in deportation proceedings because she had not kept current on her contributions.

One widely recognized need is to plan for deportation. Yet only 9 percent of CRISIS Study respondents had developed a plan prior to their removal. Interviewees reported having grown complacent regarding this risk:

“We didn't have any plan in place. It was unexpected because he'd been checking in for three years. Every year he went in and they gave him an appointment for the next year. He had a work permit. He had a social security card. Everything was going well. He could show his license, everything was well."

- Mother of two US citizen children and wife of deported immigrant

However, planning seems to have become a more urgent priority in recent months:

"Since we saw what happened with my brother, I am now prepared. I bought a car for my daughter and have a savings account for her so she can make rent in case something happens to me."

— Undocumented sister of deported immigrant

In short, interviewees acknowledged the support provided by faith communities to immigrants and their families, but some criticized the church for failing to recognize the urgency of their needs and to respond accordingly.

\section{Recommendations}

The CRISIS Study provides a snapshot of the Trump administration's deportation policies and their effect on established US residents (deportees), families and communities. In order to mitigate the harsh consequences of these policies and to promote the integrity of families and communities, we make the following recommendations.

To the Department of Homeland Security:

- Issue prosecutorial discretion guidelines that de-prioritize the arrest and removal of longterm residents; persons with US family members; and those without criminal records or with records for only minor offenses.

- Use detention only as a "last resort" and employ the least restrictive means necessary - including supervised release and other alternatives to detention (ATDs) - to ensure appearances in court, check-ins with immigration officials, and possible removal.

- Adhere to ICE's Performance-Based National Detention Standards, which recognize the need for access to legal counsel, generous family visitation guidelines, transparency on the location of detainees, and humane conditions of confinement.

\section{To Congress:}

- Pass broad legislation to reduce family-based visa backlogs; to align US legal immigration policies with the nation's economic, family, and humanitarian interests; to legalize the undocumented parents of US citizens and LPRs and undocumented persons who entered as children; and to expand equitable relief from removal. 
- Appropriate funding to DHS and the Department of Justice at levels that align with the recommendations in this report and that, in particular, assume the principled exercise of prosecutorial discretion, reduced use of detention, and expansion of community-based ATDs and legal orientation programs.

- Reduce funding to ICE in light of its indiscriminate enforcement policies and their negative impact on the safety and integrity of US families and communities.

- Provide greater oversight of formal partnerships and collaboration between state and local police and ICE and CBP to ensure that these arrangements do not undermine community safety or lead to racial profiling.

To state and local police:

- Collect data to measure the prevalence of pretextual stops and arrests (those intended to lead to removal) for minor criminal violations, with a focus on the extent to which such stops involve racial and ethnic minorities.

- Limit collaboration with ICE and CBP to prevent local police from acting as immigration agents, to promote public safety, and to ensure that no group of residents fears reporting crimes or otherwise cooperating with the police.

- Strengthen policies against racial bias in policing, and regularly train and evaluate law enforcement officers on adherence to these policies.

- Adopt and implement policies - like municipal identification cards and driver's licenses for the undocumented - that treat immigrants as full members of their communities.

To faith communities:

- Address the urgent priorities of immigrants, including the need for safe and welcoming spaces, deportation planning, transportation, access to legal representation, public safety, access to the police, and accompaniment to places where they might be vulnerable to arrest.

- Prioritize pastoral service to immigrants and their families, fully incorporate them into all faith institutions, ministries, and programs, and educate nonimmigrant members and the broader public on the immense challenges facing immigrants.

- Identify, collect, disseminate and implement best pastoral practices for accompanying and supporting deportees and their families at all stages of the removal process.

- Advocate for the generous exercise of prosecutorial discretion, humane enforcement policies that prioritize family unity and cohesive communities, expanded legal avenues to regularized status, and strong citizenship policies.

"I feel like l'm a very social, open person and when [my parents' deportation] was going on, I isolated myself from everybody. I lost friendships. I'd come home from class, and I would just lay in bed not wanting to do anything. I would have mental breakdowns. I would call my mom sobbing. There were so many times that I thought maybe this isn't even worth it, that I should just leave everything and go to Mexico with them. My sister was the same. She was way more quiet. Now she has panic attacks. She didn't have panic attacks before."

- Daughter of deported immigrant 


\section{References}

Bier, David. 2018. "60\% of Deported 'Criminal Aliens' Committed Only Victimless Crimes." Washington, DC: Cato Institute. https://www.cato.org/blog/60-deported-criminal-alienscommitted-only-victimless-crimes-few-violent-crimes.

CBP (US Customs and Border Protection). 2018. "Southwest Border Migration FY 2018." https:// www.cbp.gov/newsroom/stats/sw-border-migration\#.

Coon, Michael. 2017. "Local Immigration Enforcement and Arrests of Hispanic Population." Journal on Migration and Human Security 5(3): 645-66. https://doi.org/10.1177/233150 $\underline{241700500305 .}$.

Danielson, Michael S. 2013. Documented Failures: the Consequences of Immigration Policy on the US-Mexico Border. Washington, DC: Jesuit Refugee Service USA, Jesuit Conference of the United States, and Kino Border Initiative. http://www.jesuit.org/jesuits/wp-content/ uploads/Kino_FULL-REPORT_web.pdf.

DHS (US Department of Homeland Security). 2012. FY 2013 Budget in Brief. Washington, DC: DHS. https://www.dhs.gov/xlibrary/assets/mgmt/dhs-budget-in-brief-fy2013.pdf

- 2014. "Policies for the Apprehension, Detention and Removal of Undocumented Immigrants." Memorandum from DHS Secretary Jeh Johnson to Thomas S. Winkowski, Acting Director ICE; R. Gil Kerlikowske, Commissioner CBP; Leon Rodriguez, Director USCIS; Alan Bersin, Acting Assistant DHS Secretary for Policy, November 20. https://www.dhs.gov/ sites/default/files/publications/14_1120_memo_prosecutorial_discretion\%281\%29.pdf.

. 2018. FY 2019 Budget-in-Brief. Washington, DC: DHS. https://www.dhs.gov/sites/default/ files/publications/DHS\%20BIB\%202019.pdf.

DOJ (US Department of Justice). 2002. “Budget Trend Data 1975 through the President's 2003 Request to the Congress." Washington, DC: DOJ.

Eagly, Ingrid V., and Steven Shafer. 2015. "A National Study of Access to Counsel in Immigration Court." University of Pennsy/vania Law Review 164(1): 1-91. https://scholarship.law. upenn.edu/cgi/viewcontent.cgi?article=9502\&context=penn_law_review.

Edwards, Ryan, and Francesc Ortega. 2016. The Economic Impacts of Removing Unauthorized Immigrant Workers. Washington, DC: Center for American Progress. https://www. americanprogress.org/issues/immigration/reports/2016/09/21/144363/the-economicimpacts-of-removing-unauthorized-immigrant-workers/.

Fernandez, Manny, and Caitlin Dickerson. 2018. "Inside the Vast Tent City Housing Migrant Children in a Texas Desert." New York Times, October 12. https://www.nytimes.com/2018/10/12/ us/migrant-children-tent-camp-texas.html.

HSAC (Homeland Security Advisory Council). 2011. "Task Force on Secure Communities Findings and Recommendations." Washington, DC: DHS. https://www.dhs.gov/xlibrary/assets/ hsac-task-force-on-secure-communities-findings-and-recommendations-report.pdf. 
ICE (Immigration and Customs Enforcement). 2017. "Fiscal Year 2017 ICE Enforcement and Removal Operations Report." Washington, DC: ICE. https://www.ice.gov/sites/default/ files/documents/Report/2017/iceEndOfYearFY2017.pdf.

Kerwin, Donald. 2017. "The Besieged US Refugee Protection System: Why Temporary Protected Status Matters." New York: Center for Migration Studies. http://doi.org/10.14240/ cmsesy122017.

- "From IIRIRA to Trump: Connecting the Dots to the Current US Immigration Policy Crisis." Journal on Migration and Human Security 6(3): 191-203. https://doi. org/10.1177/2331502418786718.

Kerwin, Donald, and Daniela Alulema. 2015. "Piecing Together the US Immigrant Detention Puzzle One Night at a Time: An Analysis of All Persons in DHS-ICE Custody on September 22, 2012." Journal on Migration and Human Security 3(4): 330-76. https://doi.org/10.11 77/233150241500300402.

Kerwin, Donald, Doris Meissner, and Margie McHugh. 2011. "Executive Action on Immigration: Six Ways to Make the System Work Better." Washington, DC: Migration Policy Institute. https://www.migrationpolicy.org/research/executive-action-immigration-six-waysmake-system-work-better.

Kerwin, Donald, and Robert Warren. 2017. "National Interests and Common Ground in the US Immigration Debate: How to Legalize the US Immigration System and Permanently Reduce its Unauthorized Population." Journal on Migration and Human Security 5(2): 297-330. https://doi.org/10.1177/233150241700500205.

Lillis, Mike. 2018. "Trump plans executive order to end birthright citizenship." The Hill, October 30. https://thehill.com/homenews/house/413977-trump-plans-executive-order-to-endbirthright-citizenship.

Lind, Dara. 2018. "Trump wants immigrants to be afraid. 2 new studies show it's working." Vox, March 5. https://www.vox.com/policy-and-politics/2018/3/5/17071648/impact-trumpimmigration-policy-children.

Meissner, Doris, Donald Kerwin, Muzaffar Chishti, and Claire Bergeron. 2013. Immigration Enforcement in the United States: The Rise of a Formidable Machinery. Washington, DC: Migration Policy Institute. https://www.migrationpolicy.org/research/immigrationenforcement-united-states-rise-formidable-machinery.

Miroff, Nick, Josh Dawsey, and Maria Sacchetti. 2018. "Trump administration weighs new familyseparation effort at border." Washington Post, October 12. https://www.washingtonpost. com/local/immigration/trump-administration-weighs-new-family-separation-effort-atborder/2018/10/12/45895cce-cd7b-11e8-920f-dd52e1ae4570_story.html.

MRS/USCCB (Migration and Refugee Services, US Conference of Catholic Bishops), and CMS (Center for Migration Studies). 2015. "Unlocking Human Dignity: A Plan to Transform the US Immigrant Detention System." Journal on Migration and Human Security 3(2):159204. https://doi.org/10.1177/233150241500300203. 
NPR (National Public Radio). 2018. “How the Trump Administration's Family Separation Policy Is Playing Out." May 28. https://www.npr.org/2018/05/28/615010170/how-the-trumpadministrations-family-separation-policy-is-playing-out.

New York Times. 2018. "Kirstjen Nielsen Addresses Families Separation at Border: Full Transcript." June 18. https://www.nytimes.com/2018/06/18/us/politics/dhs-kirstjen-nielsenfamilies-separated-border-transcript.html.

Nowrasteh, Alex. 2018. "Criminal Immigrants in Texas: Illegal Immigrant Conviction and Arrest Rates for Homicide, Sexual Assault, Larceny, and Other Crimes." Immigration Research and Policy Brief No. 4. Washington, DC: Cato Institute. https://www.cato.org/publications/ immigration-research-policy-brief/criminal-immigrants-texas-illegal-immigrant.

Office of the Attorney General. 2018. Memorandum for Federal Prosecutors Along the Southwest Border: "Zero-Tolerance for Offenses Under 8 U.S.C. § 1325(a)." Washington, DC: DOJ. https://www.justice.gov/opa/press-release/file/1049751/download.

Passel, Jeffrey, and D’Vera Cohn. 2016. "Size of US Unauthorized Immigrant Workforce Stable After the Great Recession." Washington, DC: Pew Research Center. http://www.pewhispanic. org/2016/11/03/size-of-u-s-unauthorized-immigrant-workforce-stable-after-the-greatrecession/.

Rumbaut, Rubén G. 2018. "Undocumented Immigration and Rates of Crime and Imprisonment: Popular Myths and Empirical Realities." Invited address to the Immigration Enforcement and Civil Liberties: The Role of Local Police National Conference. Washington, DC: Police Foundation. https://ssrn.com/abstract=1877365.

Sedensky, Matt. 2018. "Trump's immigrant roundups increasingly net noncriminals." Associated Press, September 20. https://apnews.com/8969468fb8b2485a87ff1ff448397ba0/ Trump's-immigrant-roundups-increasingly-net-noncriminals.

Shuchart, Scott. 2018. "Careless Cruelty: Civil servants said separating families was illegal. The administration deliberately ignored us, writes form DHS adviser." Washington Post, October 28. https://www.washingtonpost.com/news/posteverything/wp/2018/10/25/ feature/civil-servants-said-separating-families-was-illegal-the-administration-ignoredus/.

Slack, Jeremy, Daniel Martinez, Scott Whiteford, and Emily Peiffer. 2015. "In Harm's Way: Family Separation, Immigration Enforcement Programs and Security on the US-Mexico Border." Journal on Migration and Human Security 3(2): 109-28. https://doi.org/10.1177/233150 241500300201.

USCCB (US Conference of Catholic Bishops). 2018. "V Encuentro of Hispanic / Latino Ministry, Missionary Disciples of God's Love: Working Document." Washington, DC: USCCB. https:// vencuentro.org/wp-content/uploads/2018/08/Working-Document-EN-8_30_18.pdf.

Warren, Robert, and Donald Kerwin. 2015. "Beyond DAPA and DACA: Revisiting Legislative Reform in Light of Long-Term Trends in Unauthorized Immigration to the United States." Journal on Migration and Human Security 3(1): 80-108. https://doi. org/10.1177/233150241500300104. 
. 2017. "Mass Deportations Would Impoverish US Families and Create Immense Social Costs." Journal on Migration and Human Security 5(1):1-8. https://doi.org/10.1177/233 150241700500101.

Wasem, Ruth Ellen. 2018. "Trump administration now has naturalized citizens in its sights." The Hill, July 17. https://thehill.com/opinion/immigration/396923-trump-administrationnow-has-naturalized-citizens-in-its-sights.

Wilkinson, Francis. 2018. "Why Trump Deports Fewer Immigrants Than Obama: Sanctuary states and cities are slowing the expulsions." Bloomberg, May 15. https://www.bloomberg. com/view/articles/2018-05-15/trump-is-deporting-fewer-immigrants-than-obama-did.

Zayas, Luis H., and Laurie C. Heffron. 2016. "Disrupting young lives: How detention and deportation affect US-born children of immigrants." CYF News, November. http://www.apa.org/pi/ families/resources/newsletter/2016/11/detention-deportation.aspx. 


\section{Attachment A: Study Methodology}

This study utilized quantitative and qualitative methodologies. First, KBI conducted a survey of deportees (Attachment B) in its Aid Center for Migrants located in Nogales, Mexico. This center provides meals and social service assistance to migrant men, women, and children deported to Nogales. The survey responses were collected between January and May 2018. During this period, KBI collected 133 survey responses. The survey contained 85 questions about the respondents' demographics; migration history; social, religious, and political engagement; apprehension, detention, and deportation history; impact of deportation on family members; and plans and needs after deportation. After conducting an initial intake, KBI requested longer interviews with migrants who reported that they had been deported after having lived for an extended period in the United States. KBI typically surveyed three to five individuals in a day. Interviews were conducted at randomly chosen dates. Very few migrants declined to participate in the survey.

Second, CMS and OJE conducted in-depth interviews with individuals who had been deported, family members of deported migrants, and others affected by deportations in Catholic parishes in Florida, Michigan and Minnesota between May and June 2018. The locations were selected to capture geographic, demographic, and sociopolitical diversity. Specific parishes were chosen based on existing connections between the sponsoring agencies and the parishes in order to facilitate access to deportees, their families and others affected by deportation. CMS and OJE conducted 21 interviews, including 12 interviews with deportees' family members, eight with parish leaders, and one (by Skype) with a deportee. The interviews lasted between 45 and 60 minutes and were conducted in Spanish or English, depending on the interviewee's preference. Participation in the interviews - which were conversational in nature and did not include any monetary compensation - was voluntary.

To be selected, participants had to have been: 1) deported within the past two years; 2) a family member of a deported individual; or 3) another member of the parish community - clergy, staff, or lay parishioner - who knew the deportee or was otherwise impacted by deportation. In order to protect the interviewees' confidentiality, researchers agreed not to identify participants by name. Attachment $\mathrm{C}$ includes the interview protocols.

\section{Attachment B: CRISIS Study Questions}

\section{Iniciativa Kino para la Frontera - Encuesta para el Comedor}

Para encuestadores/as: Si el/la encuestado/a no está seguro/a o no sabe, llene con 8888. Si el/la encuestado/a se niega a contestar llene con 9999. Respuestas con número, solo se escoge una opción.

Respuestas con letras, puede escoger más de una opción. Letras en negrillas y cursivas, entre paréntesis, son notas para los/las encuestadores/as y avisos de SALTOS (continuar en la siguiente). 


\section{INFORMACIÓN DE ENCUESTA BÁSICA}

Edad:

Género:

Años viviendo en EU:

¿Sufrió una violación de sus derechos?

¿Cuáles violaciones y por quienes?

\section{PERFIL DEMOGRÁFICO}

1. ¿Dónde residía usted antes de su ingreso más reciente a los EE. UU.?
a. Ciudad:
[RES_MIG_CITY]
b. Estado/Departamento:
[RES_MIG_STATE]
c. País:
[RES_MIG_COUN]

2. ¿Qué idiomas habla usted? [LANGUAGE]
(a) Inglés
(b) Español
(c) Otro, por favor especifique:

3. ¿Cómo calificaría su capacidad para hablar inglés? [ENGLISH]
( 1 ) Muy bien, o fluido
( 2 ) Puedo llevar una conversación básica
( 3 ) Algunas palabras
( 4 ) Nada

4. ¿Cuál es su nivel más alto de educación? [EDUC]

Por favor especifique en años.

5. ¿En qué país cumplió su nivel más alto de educación? [EDUC_COUN]

6. Antes de su deportación, ¿cuál era su situación laboral? [EMP_STATUS]

( 1 ) Empleado/a (2) Empleado/a, economía informal
( 3 ) Amo/ama de casa
( 4 ) Buscando trabajo
( 5 ) Desempleado/a

7. ¿Cuál fue su última ocupación? (¿En qué trabajó usted?)

[OCCUPATION]

8. ¿Cuánto tiempo estuvo usted en este trabajo? Por favor especifique los meses y años aproximados.

[EMP_LENGTH]

Años Meses

9. $\quad$ En su último trabajo, ¿Cuánto ganaba usted cada mes, en promedio?

[SALARY]

\section{PERFIL MIGRATORIO}

10. ¿Cuántas veces ha ingresado a los EE.UU.? [MIG_NUM] 
11. ¿Qué edad tenía la primera vez que ingresó a los EE.UU.? [MIG_AGE]

12. ¿Cuál fue su estado migratorio más reciente antes de su deportación más reciente de los EE. UU.? [IMM_STATUS]
( 1 ) Residencia permanente/Green Card
( 2 ) Asilo/Refugiado
( 3 ) U-Visa
( 4 ) Otra visa:
( 5 ) Estatus de Protección Temporal (TPS)
( 6 ) Acción Diferida (DACA)
( 7 ) Indocumentado/a
( 8 ) Otro, por favor especifique:

13. ¿En qué año recibió este estado migratorio? [No pregunte si la respuesta a la \#12 fue (7)] [IMM_STATUS_YR]

14. ¿Alguna vez regresó voluntariamente de los Estados Unidos a su país de origen por su propia cuenta sin la intervención del gobierno de los EE. UU.? [RETURN]
( 1 ) Sí
( 2 ) No
(Si la respuesta es no, SALTE a la \#16)

15. Para su regreso voluntario más reciente:
a. ¿Qué edad tenía?
[RETURN_AGE]
b. ¿Por qué regresó?
[RETURN_MOTIVE]
c. ¿Cuánto tiempo estuvo en su país de origen?
[RETURN_TIME]

16. ¿Dónde fue su lugar de residencia más reciente en los EE. UU. antes de su deportación más reciente?
a. Ciudad/pueblo:
[RES_DEP_CITY]
b. Estado
[RES_DEP_STATE]

17. Usted vivió más reciente en: [RES_DEP_TYPE]
( 1 ) Casa propia o apartamento propio
( 2 ) Casa alquilada o apartamento alquilado
( 3 ) Albergue o sin casa
( 4 ) Con amigos/familiares sin pagar alquiler

18. Cuando estaba en los Estados Unidos, ¿enviaba remesas a familiares en el extranjero? [REMIT]
[RE ( 1 ) Sí (2) No

19. ¿Cuántas personas dependientes en los EE. UU. o en el extranjero apoyaba Ud. económicamente?
a. Apoyaba plenamente a \# personas dependientes [DEPEND_FULL]

b. Apoyaba parcialmente a \# personas dependientes [DEPEND_PART]

\section{COMPOSICIÓN FAMILIAR E IMPACTOS EN LA FAMILIA}
20. ¿Cuál es su estado civil actual?
[MARITAL] 

( 1 ) Soltero/a
( 2 ) Casado/a
( 3 ) Asociación/unión doméstica
( 4 ) Relación comprometida/Acompañado/a
( 5 ) Divorciado/a
( 6 ) Legalmente separado/a

Si está casado/a o en pareja, considere a su cónyuge o pareja para cada uno de los siguientes:

21. ¿Cuál es su estado legal actual? [MARITAL_STAT]

( 1 ) Ciudadano/a estadounidense, por nacimiento ( 2 ) Ciudadano estadounidense naturalizado

( 3 ) Residente permanente/Green Card

( 4 ) Titular de visa:

( 5 ) Estatus de Protección Temporal (TPS)

( 6 ) Acción Diferida (DACA)

( 7 ) Indocumentado/a

( 8 ) Otro, por favor especifique:

22. ¿Dónde reside actualmente?
a. Ciudad:
b. Estado/Departamento:
[MARITAL_CITY]
c. País:
[MARITAL_STATE]
[MARITAL_COUN]

23. Si reside en los EE. UU., ¿desde qué año? [MARITAL_USYR]

$\begin{array}{llll}\text { 24. ¿Vivió con usted en los EE. UU.? [MARITAL_LIVE] } & \text { ( } 1 \text { ) Sí } & \text { ( } 2 \text { ) No }\end{array}$

$\begin{array}{llll}\text { 25. ¿Está actualmente empleado/a? } & \text { ( } 1 \text { ) Sí } & \text { ( } 2 \text { ) No }\end{array}$

(Si la respuesta es no, SALTE a la \#30)

26. Si trabaja en los EE. UU., ¿cuánto es su ingreso mensual? [MARITAL_INC]

27. ¿Tiene su pareja ingresos suficientes para mantenerse en los EE. UU. después de la deportación de usted? [MARITAL_INCSUF]
( 1 ) Sí
( 2 ) No

28. ¿Tiene su pareja ingresos suficientes para mantener a los niños que tiene usted en los EE. UU. después de su deportación? [MARTIAL_KIDS]
( 1 ) Sí
(2) No

29. ¿Tiene su pareja ingresos suficientes para ayudarlo/la a usted económicamente después de su deportación?

( 1 ) Sí

[MARITAL_INCSUF_DEP]

(2) No

30. ¿Cómo ha afectado su detención y deportación a su pareja?

[MARITAL_EFFECTS]
(A ) Dificultades financieras
(B ) Problemas sociales
( C ) Más peligro/menos seguro
(D) Dificultades psicológicas o emocionales
( E ) Otro, Especifique: 
31. ¿Planea su pareja quedarse en los EE. UU. o salir de los EE. UU. para unirse con usted después de su deportación? [MAR_PLANS]

( 1 ) Quedarse en los EE. UU. ( 2 ) Unirse conmigo (3) Indeciso

32. ¿Cuántos hijos tiene usted? [CHILD_NUM]

(Si la respuesta es 0, SALTE a la \#36)

33. Para cada hijo, conteste lo siguiente:

\begin{tabular}{|c|c|c|c|c|c|}
\hline & Hijo 1 & Hijo 2 & Hijo 3 & Hijo 4 & Hijo 5 \\
\hline A. Edad & $\begin{array}{l}\text { [CHILD1_AGE } \\
\text { ] }\end{array}$ & $\begin{array}{l}\text { [CHILD2_AGE } \\
\text { ] }\end{array}$ & $\begin{array}{l}\text { [CHILD3_AG } \\
\text { E] }\end{array}$ & $\begin{array}{l}\text { [CHILD4_AG } \\
\text { E] }\end{array}$ & $\begin{array}{l}\text { [CHILD5_AGE } \\
\text { ] }\end{array}$ \\
\hline $\begin{array}{l}\text { B. ¿En qué país } \\
\text { reside } \\
\text { típicamente? }\end{array}$ & $\begin{array}{l}\text { [CHILD1_CO } \\
\text { UN] }\end{array}$ & $\begin{array}{l}\text { [CHILD2_COU } \\
\mathrm{N}]\end{array}$ & $\begin{array}{l}\text { [CHILD3_CO } \\
\mathrm{UN}]\end{array}$ & $\begin{array}{l}\text { [CHILD4_CO } \\
\text { UN] }\end{array}$ & $\begin{array}{l}\text { [CHILD5_CO } \\
\text { UN] }\end{array}$ \\
\hline $\begin{array}{l}\text { C. Si } \\
\text { corresponde, edad } \\
\text { al llegar a los EE. } \\
\text { UU. }\end{array}$ & $\begin{array}{l}\text { [CHILD1_MI } \\
\text { G_AGE] }\end{array}$ & $\begin{array}{l}\text { [CHILD2_MIG } \\
\text { _AGE] }\end{array}$ & $\begin{array}{l}\text { [CHILD3_MI } \\
\text { G_AGE] }\end{array}$ & $\begin{array}{l}\text { [CHILD4_MI } \\
\text { G_AGE] }\end{array}$ & CHILD5_MIG_. \\
\hline $\begin{array}{l}\text { D. Si } \\
\text { corresponde, } \\
\text { estado legal en } \\
\text { los EE. UU. }\end{array}$ & $\begin{array}{l}\text { [CHILD1_ST } \\
\mathrm{AT}]\end{array}$ & $\begin{array}{l}\text { [CHILD2_STA } \\
\mathrm{T}]\end{array}$ & $\begin{array}{l}\text { [CHILD3_ST } \\
\mathrm{AT}]\end{array}$ & $\begin{array}{l}\text { [CHILD4_ST } \\
\mathrm{AT}]\end{array}$ & $\begin{array}{l}\text { CHILD5_STA } \\
\text { T] }\end{array}$ \\
\hline $\begin{array}{l}\text { E. Si está en los } \\
\text { EE. UU., ¿Quién } \\
\text { se encarga de } \\
\text { él/llla desde su } \\
\text { deportación? }\end{array}$ & $\begin{array}{l}\text { [CHILD1_CA } \\
\text { RE] }\end{array}$ & $\begin{array}{l}\text { [CHILD2_CAR } \\
\text { E] }\end{array}$ & $\begin{array}{l}\text { [CHILD3_CA } \\
\text { RE] }\end{array}$ & $\begin{array}{l}\text { [CHILD4_CA } \\
\text { RE] }\end{array}$ & $\begin{array}{l}\text { [CHILD5_CAR } \\
\text { E] }\end{array}$ \\
\hline
\end{tabular}

34. ¿Tuvo usted un plan para el poder legal de sus hijos antes de su deportación? [ATTORNEY_POWER]
( 1 ) Sí
( 2 ) No

35. ¿Cómo ha afectado su detención y deportación a sus hijos?

[CHILD_EFFECTS]
(A ) Dificultades financieras
(B ) Problemas en la escuela
( C ) Más peligro/menos seguro
( D ) Dificultades psicológicas o emocionales
( E ) Otro, Especifique: 
36. Para sus padres, conteste las siguientes preguntas:

\begin{tabular}{|l|l|l|}
\hline & \multicolumn{1}{|c|}{ Madre } & \multicolumn{1}{c|}{ Padre } \\
\hline A. ¿Viven? & {$[$ MOM_LIVE $]$} & {$[$ DAD_LIVE $]$} \\
\hline $\begin{array}{l}\text { B. ¿En qué país residen? } \\
{[\text { MOM_COUN }]}\end{array}$ & {$[$ DAD_COUN $]$} \\
\hline $\begin{array}{l}\text { C. Si corresponde, su estado } \\
\text { legal en los EE. UU. }\end{array}$ & {$[$ MOM_STAT $]$} & [DAD_STAT $]$ \\
\hline $\begin{array}{l}\text { D. Antes de que fuera usted } \\
\text { deportado/a, ¿Dependía su } \\
\text { madre/padre económicamente de } \\
\text { usted? }\end{array}$ & {$[$ MOM_SUPP $]$} & {$[$ DAD_SUPP $]$} \\
\hline $\begin{array}{l}\text { E. ¿Podrá usted ayudarlo/la a su } \\
\text { madre/padre económicamente } \\
\text { después de su deportación? }\end{array}$ & {$[$ MOM_FIN $]$} & {$[$ DAD_FIN] } \\
\hline
\end{tabular}

37. ¿Cómo ha afectado su detención y deportación a sus padres? [PARENT_EFFECTS]
(A ) Dificultades financieras
( B ) Problemas sociales
( C ) Más peligro/menos seguro
( D ) Dificultades psicológicas o emocionales
( E ) Otro, Especifique:

38. ¿Cuántos hermanos tiene usted actualmente? [SIB_NUM]

39. ¿Dependían sus hermanos económicamente de usted antes de su deportación? [SIB_SUPP] ( 1 ) Sí ( 2 ) No

40. ¿Cómo ha afectado su detención y deportación a su familia extendida? [FAM_EFFECTS]
(A ) Dificultades financieras
( B ) Problemas sociales
( C ) Más peligro/menos seguro
( D ) Dificultades psicológicas o emocionales
( E ) Otro, Especifique:

41. ¿Alguno de sus dependientes tiene necesidades especiales o enfermedades que requieren atención adicional o que presentan dificultades considerables para su familia?

[FAM_NEEDS]
( 1 ) Sí
( 2 ) No

(Si la respuesta es no, SALTE a la \#43)

42. En caso afirmativo, especifique: [FAM_NEEDS_DESC] 


\section{PARTICIPACIÓN SOCIAL EN LOS EE. UU.}

43. ¿En qué tipo de instituciones/lugares participaba usted en su comunidad en los EE. UU.? Marque todas las opciones que le correspondan. [PARTICIPATION]
(a ) Comités de la escuela de mis hijos/PTA
( b ) En la iglesia/actividades religiosas
(c ) Asociaciones/grupos en mi vecindad
( d ) Grupos empresariales/cívicos (p. ej. Masons, Elks, Rotary)
(e ) Grupos de orgullo étnico
(f) Grupos políticos comunitarios/estatales
( g ) Asociaciones/sindicatos laborales
( h ) Asociaciones relacionadas con su ciudad de nacimiento

(i ) Redes/grupos de derechos para el inmigrante

( $\mathrm{k}$ ) Otros grupos civiles, por favor especifique:

44. Si aplica, ¿a qué religión le correspondían sus actividades religiosas? [RELIGION]
[R
( 1 ) Cristiano-Católico
( 2 ) Cristiano-Protestante, especifique:
( 3 ) Islam
( 4 ) Budismo
( 4 ) Hinduismo
( 5 ) Otro, por favor especifique:

45. ¿Cómo se involucró en su comunidad religiosa? Marque todas las opciones que le correspondan. [REL_PART]
( a ) Asistía servicios regularmente
( b ) Grupos/comités de servicio comunitario
(c ) Reuniones familiares/sociales
(d ) Días santos
( e ) Sólo era miembro/a
(f) Amistad con pastores/ministerio/líderes
( g ) Apoyo emocional/social o económico
( h ) Grupos de oración/estudios religiosos

46. ¿Con qué frecuencia participaba en su comunidad religiosa? [REL_FREQ]
( 1 ) Diariamente
( 2 ) Una vez a la semana
( 3 ) Dos veces a la semana
( 4 ) Una vez al mes
( 5 ) Menos de una vez al mes

47. Marque todas aquellas actividades políticas en las que participó usted cuando estaba en los Estados Unidos.

[POLITICAL]
( a ) Participé en una protesta
( b ) Le escribí una carta a un político
( c ) Firmé una petición
( d ) Participé en una organización sin fines de lucro
( e ) Ninguna de estas opciones

[Si la respuesta es Ninguna de estas opciones (e), SALTE a la \#49]

48. ¿Alguna vez fueron sus actividades políticas específicamente con respeto a los derechos del inmigrante?

[IMMIG_RIGHTS]
( 1 ) Sí
( 2 ) No

49. ¿Cómo ha afectado su detención y deportación a la comunidad a la que pertenece?

[COMM_EFFECTS]
(A ) Dificultades financieras
( B ) Más peligro/menos seguro
( C ) Impactos psicológicos o sociales
( D ) Aumento en abogacía/activismo 
( E ) Otro, Especifique:

\section{PERFIL DE DEPORTACIÓN}

50. ¿Cuántas veces ha sido deportado/a por el gobierno estadounidense? [DEP_NUM]

51. Para las tres deportaciones más recientes de los EE. UU., incluyendo la deportación actual, por favor complete lo siguiente:

\begin{tabular}{|c|c|c|c|c|c|c|}
\hline $\begin{array}{c}\text { Fue } \\
\text { deportado/a } \\
\text { formalmente o } \\
\text { voluntariament } \\
\text { e? }\end{array}$ & $\begin{array}{c}\text { Mes/Año } \\
\text { de su } \\
\text { deportació } \\
\text { n }\end{array}$ & $\begin{array}{l}\text { ¿Qué } \\
\text { edad } \\
\text { tenía } \\
\text { cuando } \\
\text { fue } \\
\text { deportad } \\
\text { o/a? }\end{array}$ & $\begin{array}{c}\text { D. ¿Fue } \\
\text { declarado } \\
\text { culpable de } \\
\text { algún delito } \\
\text { antes de su } \\
\text { deportación } \\
?\end{array}$ & $\begin{array}{c}\text { Si sí, ¿qué } \\
\text { tipo de } \\
\text { delito? }\end{array}$ & $\begin{array}{l}\text { ¿Hace } \\
\text { cuántos } \\
\text { años se } \\
\text { cometió el } \\
\text { delito? }\end{array}$ & $\begin{array}{c}\text { F. ¿Por } \\
\text { cuánto } \\
\text { tiempo le } \\
\text { prohibiero } \\
\text { n el } \\
\text { ingreso a } \\
\text { EE. UU.? }\end{array}$ \\
\hline [DEP1_TYPE] & $\begin{array}{c}\text { [DEP1_DA } \\
\text { TE] }\end{array}$ & $\begin{array}{c}\text { [DEP1_A } \\
\text { GE] }\end{array}$ & $\begin{array}{c}\text { [DEP1_CRI } \\
\mathrm{ME}]\end{array}$ & $\begin{array}{l}\text { [DEP1_CRI } \\
\text { ME_TYPE] }\end{array}$ & $\begin{array}{c}\text { [DEP1_CR } \\
\text { IME_YR] }\end{array}$ & $\begin{array}{c}\text { [DEP1_BA } \\
\mathrm{N}]\end{array}$ \\
\hline [DEP2_TYPE] & $\begin{array}{c}\text { DEP2_DAT } \\
\text { E] }\end{array}$ & $\begin{array}{c}\text { [DEP2_A } \\
\mathrm{GE}]\end{array}$ & $\begin{array}{c}\text { [DEP2_CRI } \\
\mathrm{ME}]\end{array}$ & $\begin{array}{l}\text { [DEP2_CRI } \\
\text { ME_TYPE] }\end{array}$ & $\begin{array}{c}\text { [DEP2_CR } \\
\text { IME_YR }\end{array}$ & $\begin{array}{c}\text { [DEP2_BA } \\
\mathrm{N}]\end{array}$ \\
\hline [DEP3_TYPE] & $\begin{array}{c}\text { [DEP3_DA } \\
\text { TE] }\end{array}$ & $\begin{array}{c}\text { [DEP3_A } \\
\text { GE] }\end{array}$ & $\begin{array}{c}\text { [DEP3_CRI } \\
\text { ME] }\end{array}$ & $\begin{array}{l}\text { [DEP3_CRI } \\
\text { ME_TYPE] }\end{array}$ & $\begin{array}{l}\text { [DEP3_CR } \\
\text { IME_YR] }\end{array}$ & $\begin{array}{c}\text { [DEP3_BA } \\
\mathrm{N}]\end{array}$ \\
\hline
\end{tabular}

52. ¿Alguna vez ha sido deportado/a de otro país aparte de los EE. UU.? [DEP_OTHER]
( 1 ) Sí
( 2 ) No

(Si la respuesta es No, SALTE a la \#54)

53. Si es afirmativo, ¿cuántas veces ha sido deportado/a de otro país?

[DEP_OTHER_NUM]

Piense en su deportación más reciente de los Estados Unidos.

54. ¿Dónde fue su aprehensión o arresto? [APPR_LOC]
( 1 ) En el trabajo
( 2 ) En mi hogar
( 3 ) En mi comunidad/en la calle
( 4 ) Manejando
( 5 ) Después de presentarme en las oficinas de ICE
( 6 ) En la cárcel
( 7 ) Otro lugar, por favor especifique:

55. ¿A qué agencia pertenecían los oficiales que lo/a detuvieron? [APPR_AG]
( 1 ) ICE
( 2 ) $\mathrm{CBP}$
( 3 ) Policía
( 4 ) No sé

( 5 ) Otra agencia, por favor especifique:

56. ¿Cómo lo/a encontraron o identificaron las autoridades?

[APPR_FIND]

( 1 ) Tenían mi dirección de una previa orden judicial de deportación

( 2 ) Las autoridades buscaban a otra persona cuando me detuvieron 
( 3 ) Me pararon al azar

( 4 ) Hubo redada en mi trabajo

( 5 ) Un vecino o conocido me reportó

( 6 ) Mi patrón llamó a ICE

( 7 ) Fui arrestado por algún delito y después fui trasladado a ICE

( 8 ) Otra manera, por favor especifique:

(Si la respuesta es la \#7, vaya a la \#57; si es cualquiera de las otras, SALTE a la \#58)

57. ¿Cuánto tiempo estuvo en custodia criminal?

$\begin{array}{ll}\text { Años___ } & \text { [CRIM_YRS }] \\ \text { Meses } & \text { [CRIM_MONTHS }] \\ \text { Dias _ } & \text { [CRIM_DAYS }]\end{array}$

58. ¿En qué instalación estuvo detenido/a en un centro de inmigración? [DETAIN_FAC]

59. ¿Por cuánto tiempo estuvo detenido/a en un centro de inmigración?

Años [DETAIN_YRS]

Meses [DETAIN_MONTHS]

Días [DETAIN_DAYS]

60. ¿Cuándo estaba detenido/a o durante el transcurso de su caso legal, alguna vez firmó papeles que no entendía?
( 1 ) Sí
( 2 ) No

(Si la respuesta es no, SALTE a la \#62)

61. ¿En qué idioma estaban esos papeles? [PAPERS_LANG]
( 1 ) Sólo en inglés
( 2 ) Sólo en español
( 3 ) En inglés y español

62. ¿Alguna vez le avisaron de su derecho a un abogado o a una consulta legal? [LEGAL_RIGHT]
( 1 ) Sí
( 2 ) No

63. ¿Intentó usted o su familia contactar a un abogado?

[LEGAL_CONTACT]
( 1 ) Sí
( 2 ) No

64. ¿Consiguió asesoría legal? [LEGAL_AID]

( 1 ) Sí

( 2 ) No

65. Si intentó detener su deportación, ¿de qué forma lo hizo?

[IMMIG_RELIEF]
( a ) Buscando asilo
(b) U-Visa
(c ) T-Visa
( d ) Convención contra la tortura
(e ) Acción diferida [DACA]
( f ) Cancelar el proceso de remoción
( g ) Otra manera, especifique:

66. ¿Alguna vez se presentó delante de un juez? [IMMIG_JUDGE]
( 1 ) Sí
( 2 ) No 
67. Si no fue deportado/a a Nogales, ¿a qué ciudad lo/a deportaron? [DEPORT_CITY]

68. ¿Se sentía seguro/a desde dónde lo/la deportaron?

[DEPORT_SAFE]
( 1 ) Sí
( 2 ) No

69. ¿Qué pertenencias llevaba con usted cuando lo/a deportaron? [DEPORT_BELONG]
( a ) Pasaporte
( b ) Tarjeta de identificación (ID) otorgada por su país de nacimiento
(c ) Acta de nacimiento
( d ) Documentos estadounidenses (p. ej. Licencia de conducir, ID estatal)
(e ) Teléfono celular
( f ) Dinero
( g ) Ropa extra
( h ) Fotos
( i ) Otra cosa, por favor especifique:

70. ¿Cuándo fue deportado/a, ¿qué pertenencias dejó en los Estados Unidos? [DEPORT_BELONG_REMAIN]
( a ) Un auto
( b ) Casa
( c ) Ropa

( d ) Dinero (efectivo, cuentas de banco, tarjetas de crédito, etc.)

( e ) Otra pertenencia, por favor especifique:

\section{APOYO Y PLANES DESPUÉS DE LA DEPORTACIÓN}

71. ¿Qué tipo de apoyo cree usted que necesitará ahora que está en México? [DEPORT_SUPPORT]
(a) Financiero
( b ) Vivienda
( c ) Integración/ajustamiento social en la comunidad
( d ) Apoyo Emocional
( e ) Ayuda para encontrar empleo
( f ) Otro, por favor especifique:

72. ¿Aproximadamente cuánto dinero tiene a su nombre ahora? [DEPORT_MONEY]

73. Es suficiente esa cantidad para [por favor marque todas las opciones que le correspondan]: [DEPORT_MONEY_SUF]
( a ) Su próxima comida
( b ) Asegurar una vivienda temporaria
(c ) Asegurar una vivienda permanente
( d ) Regresar a su país o comunidad de origen
( e ) Mantener a los quienes dependen de usted

74. ¿Tiene a alguien quien le pueda mandar dinero desde los Estados Unidos? [DEPORT_REMIT] (1) Sí (2) No

75. ¿Tiene propiedades/terreno en su país de origen?
( 1 ) Sí
( 2 ) No

[PROPERTY] 
76. ¿Tiene a alguien en su comunidad natal quien esté dispuesto/a a mantenerlo/a? [COMM_SUPP]
( 1 ) Sí
( 2 ) No
( 3 ) Quizás

(Si la respuesta es No, SALTE a la \# 78)

77. ¿Qué tipo de apoyo estarían dispuestos/as a ofrecerle si regresara a su país? [SUPP_TYPES]
( a ) Financiero
( b ) Vivienda
( c ) Apoyo emocional
( d ) Ayuda para encontrar empleo
( e ) Integración/ajustamiento social en la comunidad
(f) Otra manera, por favor especifique:

78. ¿Con quién puede contar para apoyo financiero?

[SUPP_FIN]
( a ) Esposo/a o pareja
( b ) Padres
( c ) Hijos
(d) Familia Extendida ( e ) Amigos

79. ¿Con quién puede contar para alojarse? [SUPP_HOUSE]
( a ) Esposo/a o pareja ( b ) Padres
( c ) Hijos
( d ) Familia Extendida ( e ) Amigos

80. ¿Quién lo/la puede ayudar para encontrar un trabajo? [SUPP_EMP]
( a ) Esposo/a o pareja ( b ) Padres
(c) Hijos
(d) Familia Extendida ( e ) Amigos

81. ¿Con quién puede contar por apoyo emocional? [SUPP_EMOT]
( a ) Esposo/a o pareja
(b) Padres
(c) Hijos
( d ) Familia Extendida ( e ) Amigos

82. ¿Cree que su apoyo será suficiente para mantenerse a usted si regresara a su país? [SUPP_SUF]
( 1 ) Sí
( 2 ) No

83. ¿Se identifica usted con su país de nacimiento? [IDENTITY]
( 1 ) Totalmente
( 2 ) Algo
( 3 ) Muy poco
( 4 ) Para nada

84. ¿Planea usted regresar a los Estados Unidos? [REMIG]
( 1 ) Sí
( 2 ) No

85. ¿Cuándo regresaría a los Estados Unidos? [No pregunte si la respuesta a la \#84 fue No, No sabe (8888), o Se niega a responder (9999)] [RETURN_ESTIMATE]
( 1 ) Lo antes posible
( 2 ) En algunas semanas
( 3 ) Dentro de unos meses
( 4 ) Dentro de un año
( 5 ) Después de 1 año, pero en menos de 5 años
( 6 ) No sé cuándo pero en algún tiempo en el futuro 


\section{Attachment C - CRISIS Study Interview Protocols for Families of Deportees and for Parish Leaders}

\section{Iniciativa Kino para la Frontera: Entrevista Parroquial}

El objetivo de esta entrevista es evaluar la manera en la que las comunidades parroquiales han sido impactadas por las deportaciones masivas, particularmente bajo la nueva administración presidencial. La entrevista está diseñada para ser una conversación natural. Le haré una serie de preguntas y le pediré que elabore como sea necesario. Su participación en la entrevista y para cada pregunta es completamente voluntaria. No hay respuestas incorrectas. Siéntase libre de explicar con cuánto detalle le sea cómodo. Puede haber algunas preguntas que provocan recuerdos difíciles o respuestas emocionales. Vamos a cuidar y respetar su privacidad y confidencialidad. Tiene la opción de negarse a responder cualquier pregunta que le haga sentir incómodo. Esperamos que las respuestas de los entrevistados/as contribuyan a una mejor y más amplia comprensión del impacto de la deportación para poder brindar un mejor apoyo a los migrantes y sus familias. La entrevista nos tomará aproximadamente 45 minutos. ¿Tiene alguna pregunta?

Muy bien, empecemos.

\section{Preguntas para familiares de personas deportadas}

Estamos interesados en capturar la experiencia y el impacto de la deportación desde $s u$ perspectiva.

1. ¿Qué relación tuvo con su familiar que fue deportado/a?

2. ¿Cuándo ocurrió la deportación de su familiar?

3. Cuénteme sobre la experiencia de la aprehensión. ¿Dónde ocurrió la aprehensión? ¿Cómo se enteró que su familiar había sido capturado/a por oficiales de inmigración? ¿Cuál fue su respuesta inmediata? ¿Qué medidas tomó cuando descubrió que estaba bajo custodia? ¿Era esto parte de un plan familiar que usted había diseñado si alguna vez ocurriera una deportación?

4. Hábleme sobre la detención de inmigrantes. ¿Fue detenido/a su familiar?

En caso afirmativo, indague:

a. ¿Dónde estuvo detenido/a su familiar? ¿Durante cuánto tiempo?

b. ¿Cuál fue el impacto de la detención en su familia?

c. ¿Intentó visitarlo/la?

En caso afirmativo, pregunte:

d. ¿Cuál fue la experiencia de tratar de visitarlo/la? ¿Cuánto tiempo tuvo que esperar para poder visitarlo/la? ¿Por cuánto tiempo le permitieron visitar? La visita fue privada?

e. ¿Cómo se sintió cuando estaba dentro del centro de detención? 
f. ¿Llevó a sus hijos con usted?

g. ¿Tiene hijos o hermanos? ¿La persona deportada tiene otros hijos? ¿En caso afirmativo, los llevaron a la visita?

h. ¿Qué impacto tuvo la visita de su familiar en sus hijos/ellos?

5. Hábleme sobre el caso legal de su familiar.

a. ¿Su familiar tenia representación legal por un abogado? ¿Intentó luchar para defender su caso?

En caso afirmativo, pregunte:

b. ¿Qué avenidas de alivio atento su familiar para asegurarse?

c. ¿Intentó usted a ayudar a su familiar con su caso?

En caso afirmativo, pregunte:

d. ¿Qué papel tuvo usted en asegurar una consulta de ayuda legal y/o en otros avances sobre su caso de inmigración?

e. ¿Qué obstáculos o desafíos encontró al intentar ayudar con el caso?

6. Hábleme de los días inmediatamente anteriores, durante y posteriores a la deportación.

a. ¿Cuál fue su experiencia durante este período?

b. ¿Cómo impactó esta experiencia a su familia?

c. Específicamente, si tiene hijos/hermanos, ¿cómo se vieron afectados?

7. Considere los efectos específicos de la deportación en su hogar.

a. ¿Cómo afectó económicamente la deportación a su hogar?

i. ¿Perdió ingresos como resultado de la deportación? ¿Por qué? Si es así, ¿que cantidad?

ii. ¿Tuvo que encontrar trabajo (adicional)? ¿Cuál fue la experiencia de intentar asegurar un (nuevo) trabajo? ¿Sus hijos/hermanos tuvieron que buscar trabajo?

iii. ¿Tuvo que buscar ayuda del gobierno en forma de cupones de alimentos, Medicaid u otro tipo de ayuda? ¿Pudo acceder a los programas de ayuda social del gobierno? ¿Por qué sí o por qué no?

iv. ¿Tuvo que solicitar préstamos, formalmente o informalmente? ¿En caso afirmativo, de quién?

b. ¿Cómo afectó la deportación su residencia?

i. ¿Tuvo que mudarse? Si es así, pregunte:

1. ¿Dónde se mudó y por qué?

2. ¿Ha sido beneficiosa la mudanza o dañina? ¿En qué sentido?

ii. ¿Tuvieron que cambiar de escuela sus hijos? Si es así, pregunte:

1. ¿Cuál es el impacto a corto y a largo plazo de este cambio?

c. ¿Cuál ha sido el impacto en la salud mental de su familia?

i. Considere su propia salud mental. Pregunte:

1. ¿Ha experimentado síntomas de ansiedad, depresión u otros desórdenes mentales/emocionales?

2. ¿Han cambiado sus patrones de comportamiento? Si es así, pregunte: 
¿Se vio afectada su salud física, poder de concentración en el trabajo, capacidad de cuidar a sus hijos u otras áreas de su vida?

ii. Considere a sus hijos/hermanos. Pregunte:

1. ¿Han experimentado síntomas de ansiedad o depresión?

2. ¿Ha cambiado su comportamiento? Por ejemplo, ¿se han vuelto más aislados, están actuando fuera de lo normal o tienen dificultades para concentrarse en el hogar, la escuela y/o en sus actividades extracurriculares?

8. Considere la relación actual de su familia con el miembro de su familia que fue deportado. ¿Cómo es esa relación ahora?

a. ¿Cómo es tu relación ahora?

b. Mantiene el contacto con su familiar deportado? ¿Con que frecuencia se hablan?

c. Si usted tiene hijos/hermanos, ¿cómo es la relación de sus hijos con su familiar deportado/a?

d. ¿Han cambiado estas relaciones a lo largo del tiempo? En caso afirmativo, pregunte: ¿En qué sentido?

e. ¿Cómo está su familiar social y económicamente?

f. ¿Usted es capaz de apoyarlo/a económicamente?

g. ¿Recibe su familiar alguna otra forma de apoyo (emocional o económico, pida que especifique) desde aquí en los Estados Unidos o en el extranjero?

h. ¿Qué planes tiene como familia? Indague: ¿Podría alguna vez mudarse al extranjero?

i. ¿Cree que su familiar intente volver a vivir en los EE. UU? ¿Por qué sí o por qué no?

9. Usted es miembro de esta comunidad parroquial. ¿Le ha ayudado la iglesia a usted y a su familia durante el proceso de la deportación?

En caso afirmativo, pregunte:

a. ¿En qué sentido?

b. ¿Este apoyo continuó en el tiempo?

¿Tiene algo más que quiera agregar?

Gracias por su tiempo. Agradecemos su participación. 


\section{Iniciativa Kino para la Frontera: \\ Entrevista Parroquial}

El objetivo de esta entrevista es evaluar la manera en la que las comunidades parroquiales han sido impactadas por las deportaciones masivas, particularmente bajo la nueva administración presidencial. La entrevista está diseñada para ser una conversación natural. Le haré una serie de preguntas y le pediré que elabore como sea necesario. Su participación en la entrevista y para cada pregunta es completamente voluntaria. No hay respuestas incorrectas. Siéntase libre de explicar con cuánto detalle le sea cómodo. Puede haber algunas preguntas que provocan recuerdos difíciles o respuestas emocionales. Vamos a cuidar y respetar su privacidad y confidencialidad. Tiene la opción de negarse a responder cualquier pregunta que le haga sentir incómodo. Esperamos que las respuestas de los entrevistados/as contribuyan a una mejor y más amplia comprensión del impacto de la deportación para poder brindar un mejor apoyo a los migrantes y sus familias. La entrevista nos tomará aproximadamente 45 minutos. ¿Tiene alguna pregunta?

Muy bien, empecemos.

\section{Preguntas para los Feligreses}

1. Cuénteme un poco sobre usted. En particular, ¿cuál es su relación con esta comunidad parroquial?

a. Indague: ¿Está activo/a en la comunidad parroquial?

b. Pregunta: ¿Mantiene posiciones de liderazgo?

c. Siga con: Por favor describa la naturaleza y la intensidad de su participación en la parroquia y en la comunidad en general.

2. Cuénteme sobre la composición demográfica de su parroquia.

a. ¿Esta parroquia / comunidad de fe tiene una membresía inmigrante considerable?

En caso afirmativo, ¿sabe qué porcentaje de los miembros de la parroquia son inmigrantes o viven en familias inmigrantes?

b. Por favor, describa las dinámicas entre la población no inmigrante y la población inmigrante dentro de la iglesia y con la población inmigrante en la comunidad local.

3. Las deportaciones de los EE. UU. han incrementado en altas proporciones en los últimos años; y el temor a la deportación es particularmente alto bajo la nueva administración presidencial. ¿Cómo ha afectado esta amenaza creciente a su parroquia y a la comunidad cercana, si es que ha afectado?

a. Considere la comunidad que rodea la parroquia, donde vive la mayoría de los feligreses. ¿Cómo ha sido afectado el vecindario por las deportaciones? Si es así, cómo?

i. Considere el grado de amenaza de deportación. ¿Tiene la gente más miedo? Si es así, ¿cómo puede reconocerlo?

ii. Considere las actividades diarias de los migrantes. ¿Han cambiado los patrones regulares de la vida de la gente? Es decir, ¿han cambiado sus 
actividades cotidianas (manejar, asistir a la escuela, ir a trabajar, ir a la iglesia, salidas sociales, buscar servicios sociales, legales y de salud, participar en actividades voluntarias y el activismo)? En caso afirmativo, ¿cómo han cambiado?

iii. Considere la participación cívica. ¿Han cambiado los niveles de participación en actividades voluntarias, abogacía, y activismo sobre la migración? En caso afirmativo, ¿en qué formas han cambiado?

b. Considere el tejido social de la parroquia. ¿De qué manera la deportación, o la amenaza de deportación, fragmenta o une a la comunidad?

i. ¿La deportación separa a las familias de la parroquia?

ii. ¿La deportación ha perjudicado las relaciones entre los feligreses inmigrantes y no inmigrantes, o entre los latinos y los no latinos?

iii. ¿Hace la deportación que la comunidad se una sobre los derechos de inmigrantes? En caso afirmativo, en qué formas?

iv. ¿En qué actividades o acciones, si las hay, está involucrada su parroquia para contrarrestar la deportación y sus efectos?

c. ¿Alguien de su parroquia ha sido deportado? Si es así, ¿puede describir lo que sucedió?

i. ¿Cuáles son los impactos más amplios de tales deportaciones? ¿En la parroquia? ¿En la familia dejada atrás? ¿En la persona deportada?

ii. ¿Cómo ayudó la iglesia y los feligreses a la familia después de la deportación?

¿Tiene algo más que quiera agregar?

\section{Gracias por su tiempo. Agradecemos su participación.}




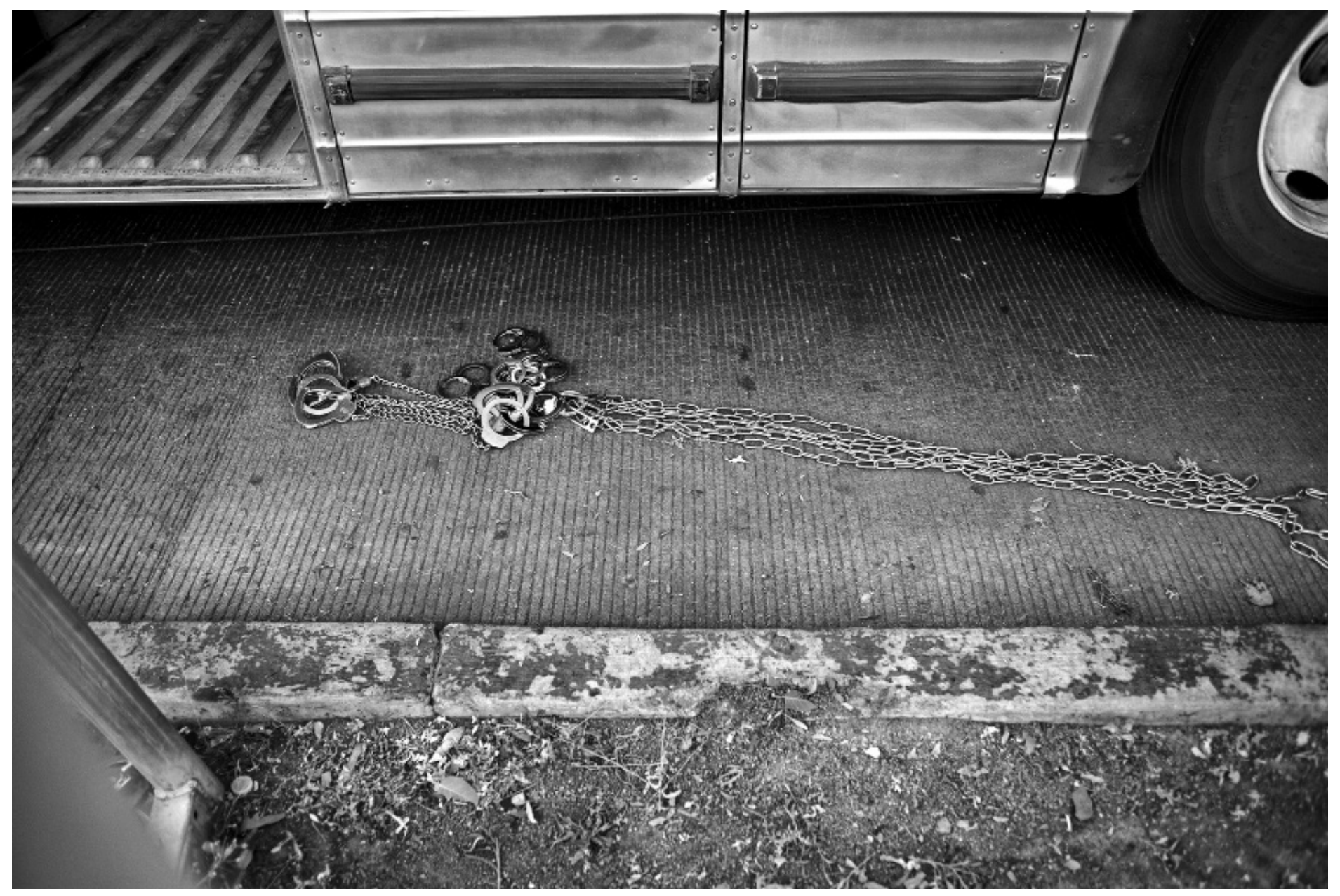

Handcuffs taken off of people getting off the bus in Nogales, Arizona before walking into Mexico to be officially deported. Photo: Greg Constantine. 
Kino Border Initiative

https://www.kinoborderinitiative.org/

Center for Migration Studies

http://cmsny.org/

Office of Justice and Ecology

http://jesuits.org/socialjustice 